\title{
Review of Isolated Matrix Inverters: Topologies, Modulation Methods and Applications
}

\author{
Oleksandr Korkh, Andrei Blinov*(D), Dmitri Vinnikov and Andrii Chub $\mathbb{D}$ \\ Department of Electrical Power Engineering and Mechatronics, Tallinn University of Technology, \\ 19086 Tallinn, Estonia; oleksandr.korkh@taltech.ee (O.K.); dmitri.vinnikov@taltech.ee (D.V.); \\ andrii.chub@taltech.ee (A.C.) \\ * Correspondence: andrei.blinov@taltech.ee
}

Received: 20 April 2020; Accepted: 7 May 2020; Published: 11 May 2020

check for updates

\begin{abstract}
This paper presents a review of isolated matrix inverters. The study contributes to creating a point of reference for a comprehensive classification of existing solutions. Over 30 topologies were reviewed, and the main advantages and disadvantages discussed. Applications of isolated matrix inverters are summarized in a tabular form to demonstrate their flexibility for different power and voltage levels achieved due to the presence of a transformer. These inverters have been proposed for the uninterruptible power supplies, high and low-voltage/power photovoltaic systems, low-power fuel cell, different low- and high-voltage battery and/or electric vehicle chargers, audio amplifiers. The fully controlled switches on both terminals of these converters typically can provide the bidirectional power transfer capability, which is also addressed for most of the topologies, but requires some modification in their modulation strategy. Average efficiency of today's isolated matrix inverters is comparable with the two-stage power converters; however, they can provide higher reliability and lower cost.
\end{abstract}

Keywords: isolated matrix inverter; current source inverter; voltage source inverter; bridge; push-pull; modulation methods; soft switching

\section{Introduction}

Climate change caused by human activities resulting in excessive pollution by greenhouse gases is considered the main threat to the sustainable development of humanity [1]. The first attempt to limit the pollution was reflected in the Kyoto Protocol of 1992 [2]. Later, it was recognized that this initiative is not sufficient to adequately address climate change [3]. Eventually, the Paris Agreement of 2016 was introduced to strengthen national efforts towards climate change mitigation [4]. The energy intensity is considered the key metric for national economies and reflects energy use in equivalent kilograms of oil needed to produce a unity of the national global domestic product [5]. This can be improved via decarbonization of energy generation facilities and improvement of energy efficiency of industry, building stock, agriculture, etc.

Renewable energy generation is considered the main solution for decarbonization of the energy generation industry [6,7]. Even though hydroelectric and biomass technologies dominate this sector, non-conventional renewables are projected to increase their share to over $60 \%$ with the dominance of electrical energy generation [8]. This will be supported by accelerated rates of electrification of the industry and the private sector. It is expected that even heating will be widely electrified in the next 30 years [9]. Evidently, electrification will require new approaches to energy processing and transportation. Power electronics is becoming a critical technology that can enable the paradigm shift to decentralized renewable energy generation and massive electrification [10]. Emerging applications of power electronics are countless: renewable energy generation from multi-MW to sub-kW scale, electric 
and hybrid electric vehicles and their on- and off-board charging, high-voltage DC energy transmission, battery energy storage systems (BESS) from utility level to the behind-the-meter applications, energy harvesting for Internet of Things devices, wearables, microgrids (AC, DC and hybrid) and their interconnection, energy-efficient buildings with on-site energy generation, etc.

The increased use of alternative and renewable energy sources, like wind and solar, together with the development of energy storage technologies, such as Li-ion batteries, supercapacitors and fuel cells, fosters the need for various power electronic converters in the present electric energy systems [11-15]. Electronic power technology for large-scale renewable energy generation is approaching maturity and sees evolutional improvements in topologies, used semiconductor and passive components. At the same time, disruptive innovation is expected in their control by the integration of smart functionalities secured with blockchain (distributed ledger) technology [16,17]. Meanwhile, the dispersion of energy generation is associated with the new incentives for decarbonization of building stock. It has been shown that nearly zero energy buildings can be economically viable when energy-saving construction technologies are complemented with on-site generation of heat and electricity [18]. This has resulted in the rapid growth of residential renewable energy generation technologies, such as rooftop and building integrated photovoltaic (PV) systems, low-voltage residential BESSs, small wind turbines, fuel cells (FCs), etc. $[19,20]$. All of these feature different voltage and power levels and thus require numerous power electronic converter types. Moreover, additional converters are required to interface systems having various voltage levels with common DC or AC bus [21,22]. Increased electrification will require energy storage not only to balance the utility grid to withstand intermittent variations in renewable energy generation, but also to provide an uninterruptible power supply to critical loads $[23,24]$. Other growing markets that benefit from advancements in power electronic technologies are hybrid and electric vehicles [25], electrified railway [26], variable speed drives across industry [27] and flexible power systems [28]. Increased demand for the development of technologies based on power electronic converters put additional pressure on the industry to provide new solutions with minimal cost and high reliability to facilitate faster decarbonization.

In the BESS, PV and FC applications, a power electronic converter has to operate with a variable DC source that should be interfaced with the AC grid. In such systems, the main challenges are mostly associated with providing voltage step-up from a low-voltage energy source, like a battery or to provide galvanic isolation as a safety measure, such as required in EV charging. Typically, to achieve demanded functionality, a two-stage power electronic system is used (Figure 1a) [29-33]. Variable input DC voltage is first stabilized at a DC-link capacitor by a DC-DC converter that often features a high-frequency (HF) transformer (HFT) for both voltages matching and the galvanic isolation. It is then followed by an inverter stage that converts the stabilized DC voltage of the appropriate level into the AC voltage. These systems offer a good regulation range and are widely used in practical applications [29-34].

An alternative approach is to apply isolated DC-AC topologies without an evident intermediate DC-link. In these converters, the HFT secondary voltage can be converted to low frequency (LF) AC using an active rectifier and unfolder (Figure 1b) [35-42], or by using single HF AC to LF AC conversion (Figure 1c) [43-53]. Despite both of these approaches are commonly referred to as single-stage DC-AC converters, the systems with unfolding stage technically feature an additional low-frequency link (with rectified sine-wave) and, therefore, are considered as a quasi-single stage in this paper. On the other hand, the topologies with unified HF AC to LF AC stage are performing AC-AC conversion directly, using bidirectional semiconductor switches, which is a distinctive feature of matrix converters [54]. In the literature, such systems are also referred to as HF-link inverters [39,52], cycloconverters [43,48] or single-stage inverters (converters) [30,32], but are all considered as isolated matrix inverters in this review. These systems are often capable of transferring power in both directions and can achieve soft switching conditions in semiconductors with advanced modulation methods [46-56]. Such features, together with a wide range of possible industrial applications, have attracted increased interest of research groups in isolated matrix inverters for many years. 
Modern single-stage converters with fully controlled semiconductor devices started to appear in the literature in the late 1980s [57], mostly targeting uninterruptible power supplies [58,59]. Later, their application area was extended to PV microinverters [60,61], FC [42,62,63], Li-ion battery storage [64], railroad [65], electric vehicle charging [66], motor drive [67] and residential applications [22,62]. Currently, the two-stage galvanically isolated inverters are an industry-accepted technology established in numerous applications, while the quasi-single-stage has also been used in emerging applications such as PV microinverters [68,69], recently adopted in residential BESSs [70-73]. The isolated matrix inverters are an emerging technology that has not yet reached maturity and good industrial awareness; however, this technology shows good potential for industrial adoption, as was demonstrated in [53,74].

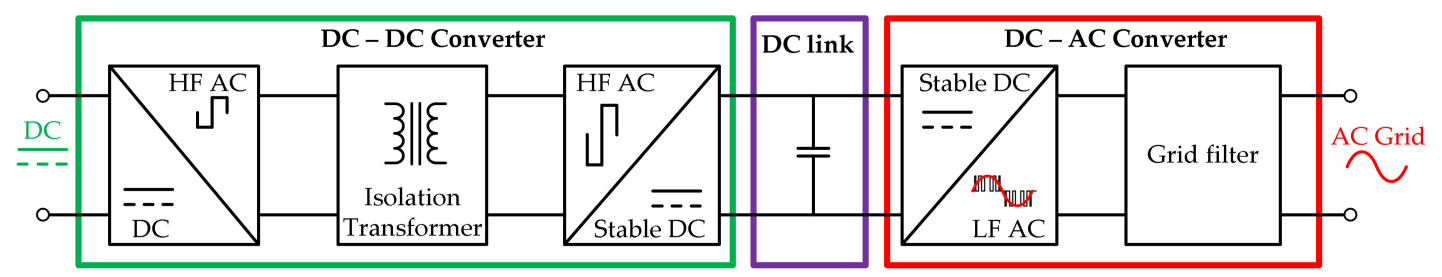

(a)

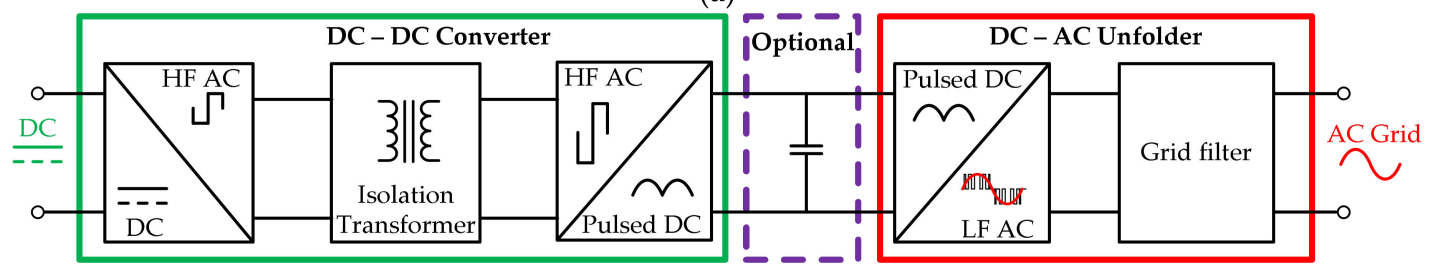

(b)

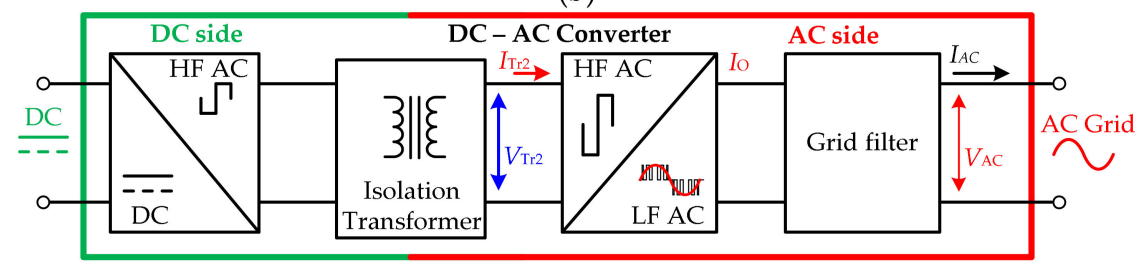

(c)

Figure 1. General structure of isolated matrix inverters: (a) two-stage, (b) quasi single-stage, (c) single-stage. LF AC—grid frequency; HF AC—switching frequency.

Despite a multitude of isolated matrix inverter concepts presented for various applications, no classifications or reviews summarizing the features and potential of this technology have been reported. The aim of this paper is to give an overview of existing single-stage matrix inverters, classify their topologies, modulation methods and applications in order to get the reader a better understanding of the potential and limitations of such systems. The paper is arranged as follows: in Section 2, the classification based on topology types and modulation methods is proposed. Section 3 addresses the current source inverter (CSI) based topologies, followed by the description of the voltage source inverter (VSI) based topologies in Section 4. Section 5 discusses the main features and applications of the highlighted topologies. Finally, the conclusions and further research directions are presented.

\section{Systematization and Classification}

Various isolated matrix inverter topologies have been reported for different applications, ranging from low-voltage and low-power [60,61,75] to high-voltage high-power [76], which proves the versatility of this technology and justifies the need for systematization of existing knowledge to establish points of reference. As mentioned in the previous section, a common property of such converters lies in the absence of an evident DC-link and presence of the direct AC-to-AC conversion stage. Generally, the DC-side of an isolated matrix inverter features a half-bridge (HB), full-bridge (FB) or push-pull (PP) stage that is connected to the primary winding of HFT. The AC-side connects the HFT secondary 
to the grid using HF AC to LF AC stage. The AC-side can be a current-source inverter (CSI) type [46] or a voltage-source inverter (VSI) type [77]. In the CSI-type, the current $I_{O}$ is constantly flowing in one of the legs and either LC or LCL filter is used (Figure 2a), whereas the VSI-type has the diagonals switched with certain dead time and generally utilizes a CL filter, and in this case, the current $I_{O}$ is not continuous (Figure 2b).

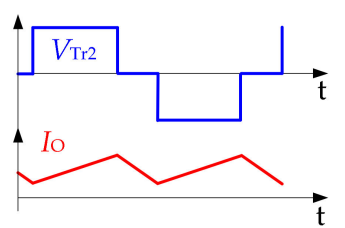

(a)

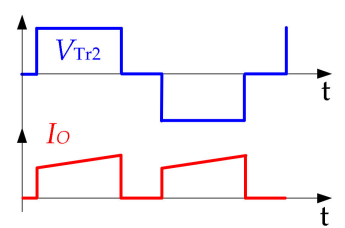

(b)

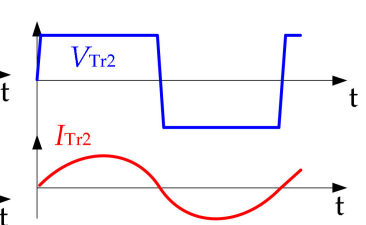

(c)

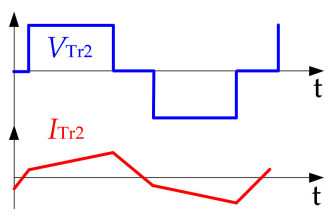

(d)

Figure 2. Generalized representation over one switching period of currents and voltages for different isolated matrix inverter types and availability of resonant tank: (a) current source inverter (CSI), (b) voltage-source inverter (VSI), (c) resonant, (d) non-resonant.

The converters that are based on the two-winding transformer are typically HB- or FB-type $[57,60,61]$. On the other hand, central-tapped or multi-winding transformers enable the use of other configurations, like PP [78] or three-leg [79]. The PP topologies generally employ the central tap transformer, and the semiconductors have double voltage stress, but, at the same time, they allow for the reduction of the number of semiconductor devices.

Most modern isolated matrix inverters feature soft switching in semiconductors that is achieved using special modulation strategies [46-56], resonant circuits [60,66,80] or active auxiliary circuits [81-85]. In addition, these methods aim to reduce semiconductor voltage stresses [85]. For the resonant topologies, the transformer current $I_{\mathrm{Tr} 2}$ is usually close to the sinusoidal (Figure 2c), whereas in the case of non-resonant topologies, the shape of current $I_{\operatorname{Tr} 2}$ is typically close to square-wave or trapezoidal (Figure 2d).

The sine wave modulation can be applied either for DC or AC sides of the converter. In the case of the DC-side modulation (primary side modulation), the shape of the output voltage (current) is formed using pulse width modulation (PWM) [47] or phase shift modulation (PSM) [48] applied to the DC-side switches. The AC side, in this case, is usually working as a rectifier. Another common strategy is the secondary side modulation. In this case, the DC switches are working as an inverter, forming the square wave voltage pulses at the HFT primary. After this, the AC-side switches are forming the required shape of the voltage (current) based on PSM [46] or PWM [47]. For the resonant topologies, the frequency modulation (FM) [66] is usually applied, which allows changing the gain under different power ratings.

Two main strategies of the PWM are used — unipolar and bipolar. Unipolar PWM(UPWM) [47,49,75] is widely employed and allows achieving zero voltage switching (ZVS) for the AC-side switches. The utilization of the bipolar PWM (BPWM) [81] has been reported to have lower total harmonic distortion than the UPWM. The PSM modulation is usually based on only one shift carrier for the CSI $[46,48]$, while in the VSI based topologies, PSM with more than one phase shift is typically used to achieve better quality of the output voltage [86]. More sophisticated methods additionally use FM to increase the ZVS range [66]; moreover, the amplitude modulation (AM) [80] was also addressed. These are the low-level modulation techniques that are employed in converter modulators to generate the switching sequence within a single switching period and ensure that an inverter can perform the input voltage regulation and the output current control (Figure 3). Hence, this paper considers modulation strategy as the main control feature in each reviewed topology. To achieve the LF sinusoidal voltage/current at the output, a higher-level control/modulation (controller in Figure 3a) method has to be applied to define the control variables applied to the low-level modulators $\left(V_{\bmod }\right)$ across the grid frequency period, i.e. PWM duty cycle, PSM phase shift or both. Typical higher-level control/modulation methods are the sinusoidal modulation [58] in the one-phase system, the space vector modulation [87] 
in the three-phase, or model predictive control [88]. They define the input parameters applied to the low-level modulator(s) typically based on PWM or PSM, as discussed above.

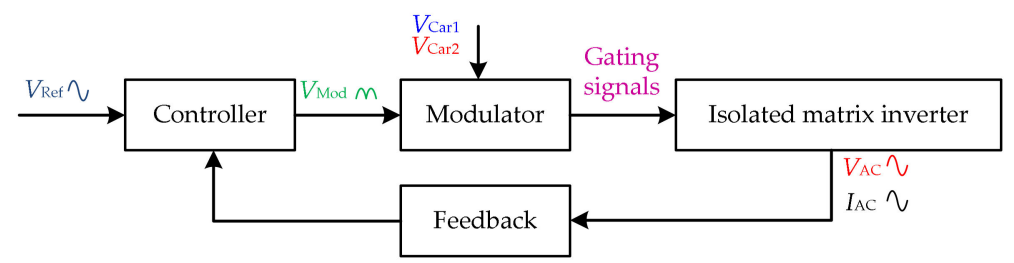

(a)

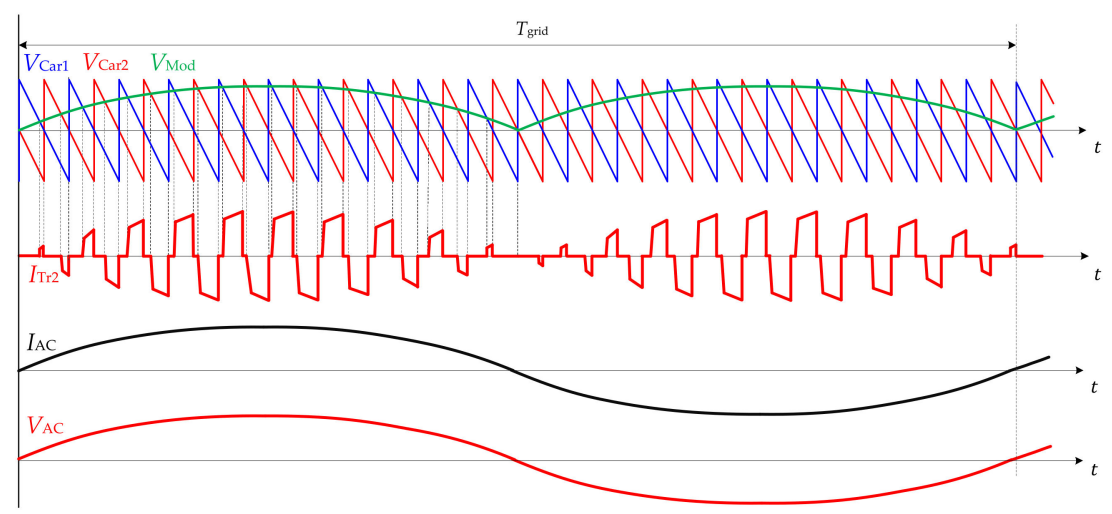

(b)

Figure 3. Generalized representation of (a)control and (b) modulation for the isolated matrix inverters.

The isolated matrix inverters could be realized with the metal oxide semiconductor field-effect transistor (MOSFET) [89], the insulated-gate bipolar transistor (IGBT) [90], gate turn-off thyristor (GTO) [91] or the reverse blocking IGBT (RB IGBT) [92-95] semiconductors, depending on the power and voltage level and application. The DC side is generally formed by unidirectional devices (Figure 4a), while the AC side usually features bidirectional switches (Figure $4 \mathrm{~b}$ ). The bidirectional switches for the AC side are typically realized by two identical devices in common source (emitter, cathode) configuration or the antiparallel reverse blocking switches can be applied. In some cases, the bidirectional switches with the middle connection point can also be used (Figure 4c) (see also [96-107]).

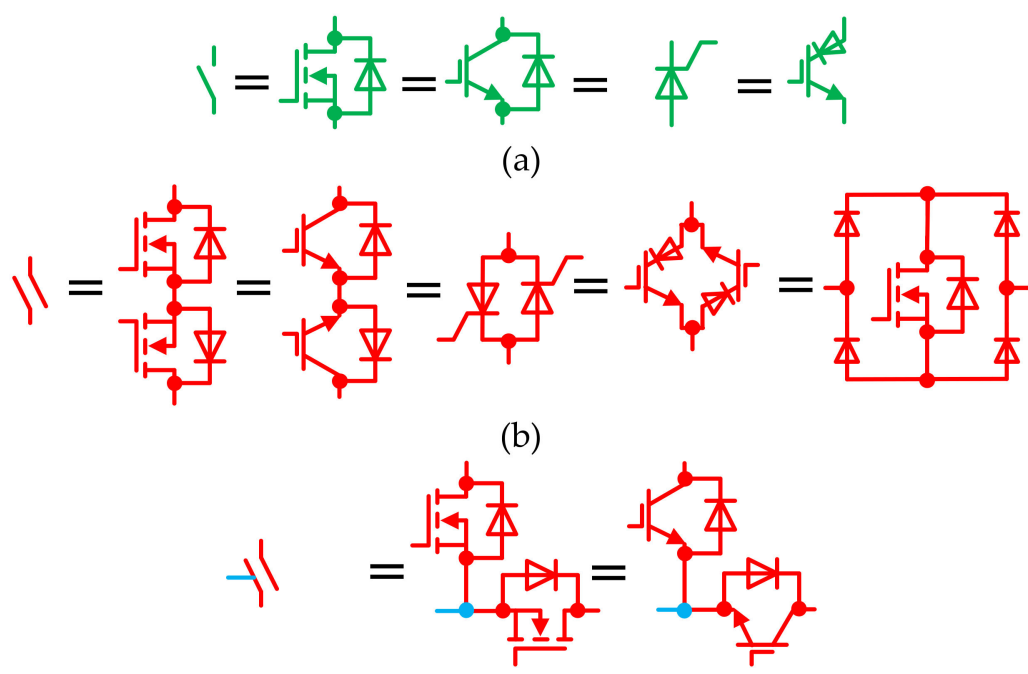

(c)

Figure 4. The types of the semiconductors (a) unidirectional switch, (b) bidirectional switch, (c) bidirectional switch with the middle connection point. 
The classification presented in Figure 5 divides the isolated matrix inverters by the type of the AC side: CSI- or VSI-based. Second, they are classified by the conversion type-resonant or non-resonant, and third, by the configuration of the topology: bridge, PP. Finally, the reported modulation types for the particular configuration are given.

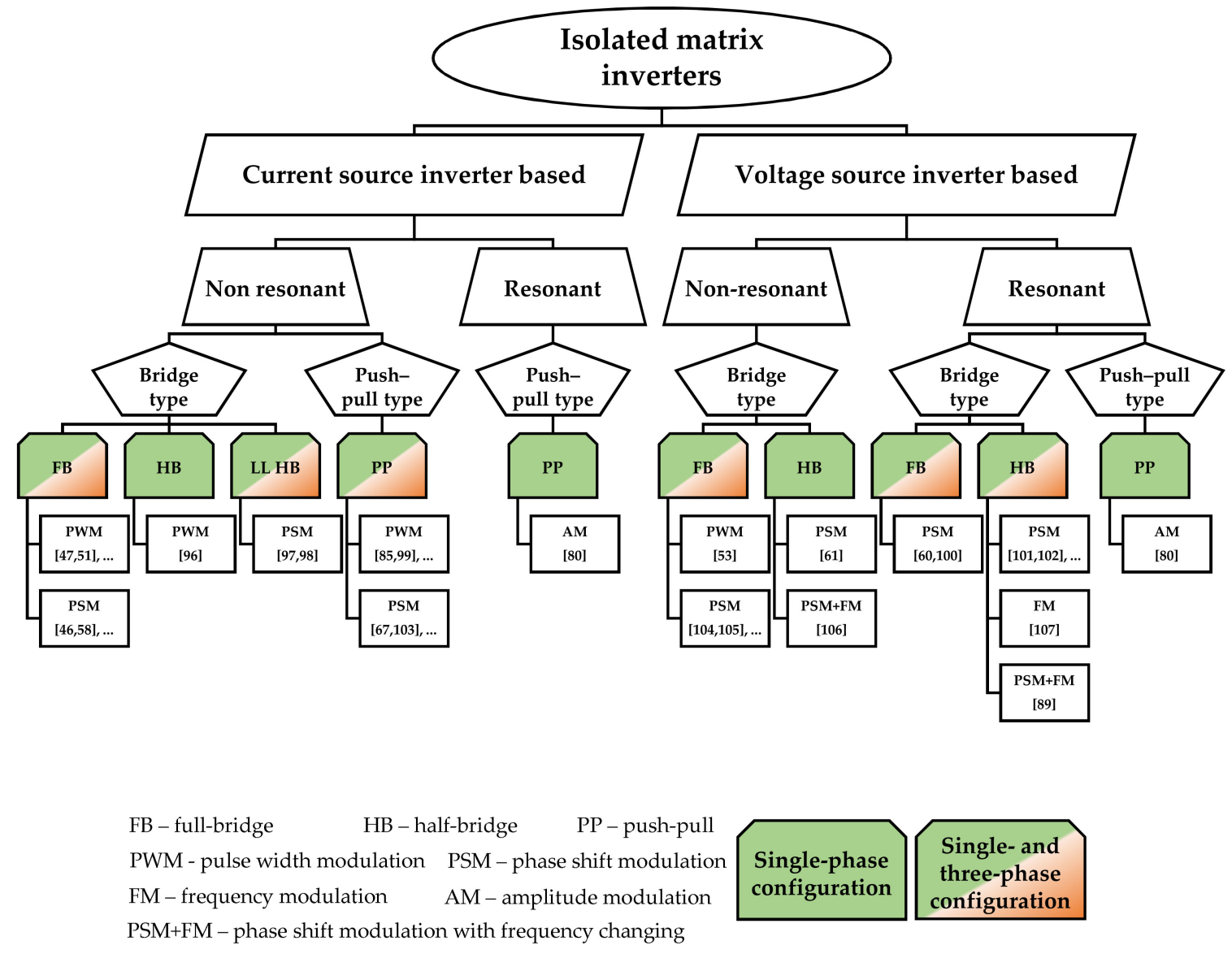

Figure 5. Classification of the isolated matrix inverters.

\section{CSI Based Topologies}

This section addresses the topologies of the isolated matrix inverters with a grid side switching stage based on the CSI. The subsections are organized according to the fourth hierarchical level of the classification from Figure 5.

\subsection{Non-Resonant Bridge Topologies}

\subsubsection{FB Configuration}

The history of the FB inverter configuration presented in Figure 6 started close to 1980, when this type of topology was proposed for railroad applications [57] and afterwards for uninterruptible power supplies [58]. At that time, the developments of the new types of the ferrite materials and possibilities to increase the switching frequency with new types of semiconductors allowed for a decrease of losses and sizes of the magnetic components, resulting in the improvement of the efficiency of the system in general. The topology consists of four main parts: the DC-side bridge, the AC-side bridge, the HFT and the output grid filter. The DC-side bridge consists of four switches that work as an inverter, which forms the high-frequency pulses. The transformer provides galvanic isolation between the two sides and allows them to step up/step down voltage. The AC-side bridge can form the sinusoidal voltage output or work as a rectifier, depending on the modulation method. The output AC-side LCL filter is 
used to filter the high-frequency pulses. Given the realization of bidirectional switches in the AC side using two discrete devices, this leads to a distinct disadvantage-a relatively high number of active semiconductor devices required.

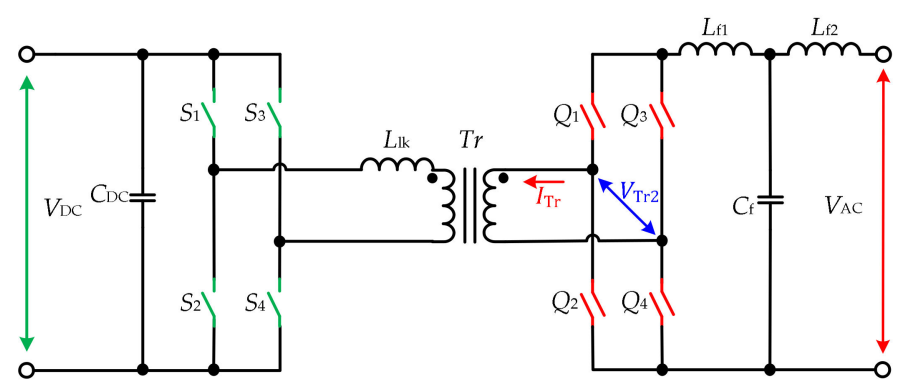

(a)

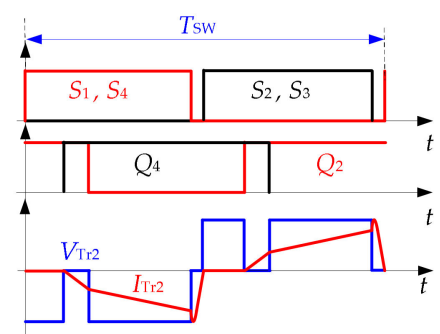

(b)

Figure 6. Full-bridge (FB) configuration (a) and modulation(b) proposed in [52].

Another major challenge for the isolated FB configuration inverter topology is that the transformer leakage inductance and the output filter inductor both serve as current sources for the AC-side bridge. Thus, the AC-side bridge operates as a current breaker, which endures high-voltage spikes due to the cutoff of the leakage inductor current. The natural commutation principle for this converter was proposed in [59]. In addition, various other modulation methods using DC- or AC-side switches were presented for the current topology [46-52]. These methods typically allow utilizing energy stored in the leakage inductance to create soft switching conditions for semiconductors, which also particularly or fully solves the mentioned problem of high-voltage overshoots. The topology features the capability of bidirectional power flow without any additional auxiliary circuit.

In [46], the $40 \mathrm{kVA}$ bidirectional converter for medium voltage converter (MVC) application was proposed. This work presents a special multi-mode quasi-resonant PSM method, which allows achieving soft switching in all semiconductor devices. The additional snubber capacitor is added for DC-side semiconductors and RCD for the AC side to reduce turn-off losses and ringing. Special multi-mode modulation allows the creation of the additional quasi-resonant interval, which is activated near the zero-crossing point. It is utilizing the resonant circuit formed by the DC-side snubber capacitor and transformer leakage inductance to achieve soft switching at the current zero-crossing point. The details of the modulation method are described in [65]. The experimental waveforms confirm that the method is verified, and the converter can operate without any additional damping circuit for the leakage inductance energy. At the same time, the optimization of the transformer and snubber capacitance can be a point of the discussion, because this can significantly influence of the converter efficiency, especially at the higher step-up ratio of the transformer.

Two UPWM based modulation methods for the FB isolated matrix inverter are reported in [47], both of these methods allow achieving the soft switching for the AC-side switches. In contrast, the DC side has only the ZVS turn-on transient. The first method allows operating four switches at the AC side at line frequency, further reducing the remaining switching loss and improving the efficiency. The authors applied the hybrid structure of the switches at the AC side -four of them are IGBT with grid frequency switching and four MOSFET with high working frequency. This allows price reduction of the converter, which was the authors' aim. The second modulation method is proposed for the full MOSFET bridge configuration. In this method, two of the switches working with the line frequency, two-as synchronous switches, and all the other are forming the output voltage. The authors verified the experimental 1.2-kW prototype with 400-V DC input voltage and 240-V AC RMS output using one to one isolation transformer. The peak efficiency of the system is $96 \%$ for the full silicon carbide (SiC) MOSFET design. In [108], the same group of authors presented applications for this converter in the high-frequency distributed power delivery system. This utilization allows elimination of the traditional low-frequency transformer and its replacement it with HFT. The potential target application is air and ground transportation and renewable energy systems. 
In some studies, the leakage inductor energy is redirected to the additional auxiliary circuit, which allows the clamp of the voltage overshoot. In [48], the new modulation method based on the DC-side PSM is addressed for the FB inverter operation. For the minimization of voltage overshoot across AC-side switches, the clamping circuit with the rectifier bridge, capacitor and DC-DC converter is applied. The energy from the AC side is returned to the DC input and reused again in the converter. The topology is verified with $1 \mathrm{~kW}$ with $270 \mathrm{~V}$ of input and 100-V RMS at the output as UPS inverter. Other clamping circuit approaches were addressed in [49-51,109]. These papers present different types of regenerative flyback snubber. Since this snubber is technically a separate converter, in addition to voltage clamping, it can provide additional features for the topology: reduce the amount of the circulation current through the main switches, improve the soft-start procedure or improve the quality of the current in the case of non-unity power factor. The energy stored in the snubber capacitor can be utilized in two ways-being reused in the next switching cycle of the conversion, as proposed in $[49,50]$ or transferred back to the DC side and reused again as shown in [109]. In addition, it is claimed to allow improving the efficiency of the converter in general. In [110], different snubbers for the minimization of the influence of high step-up transformer are analyzed for the case of the integration of low-voltage DC source to the grid. On the other hand, the utilization of the snubbers requires an additional transformer or two flyback transformers, switches, diodes, capacitors and additional control channels and isolated drivers. The utilization of this snubber can be more suitable for the high-power converter. For the lower-power converters, this solution can be less optimal, considering the price and overall complexity.

Many high-power converters commonly use bridge-type topologies due to the better utilization of the switches and lower stresses. The FB topologies can be extended to the three-phase grid system, as presented in $[53,59,76,111]$. In this case, at the AC side, an additional leg is supplied and the modulation method is extended for the three-phase system (Figure 7).

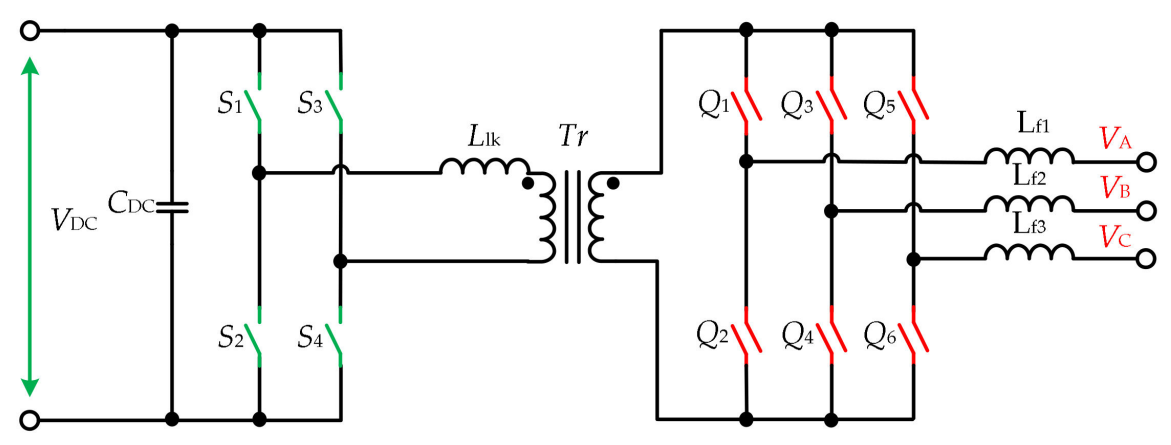

Figure 7. Three-phase FB configuration.

\subsubsection{FB Configuration with Three Legs at the DC Side}

In [79], the AC side PSM modulated PV microinverter is proposed (Figure 8). The topology utilizes three switching legs and a special high-frequency transformer. The additional bridge leg operates with a phase shift to the main bridge and allows generation of the two-step voltage waveforms, which are afterwards converted to the $\mathrm{AC}$ voltage. The two-step voltage allows reducing the ringing of the AC-side switches. The topology allows achieving the soft switching in all semiconductors at the AC side, while on the DC side, only two switches have hard transients. This solution is suggested to improve the efficiency of the system compared to the topology with the RCD snubber at the AC side. The peak efficiency reported is $95 \%$. 


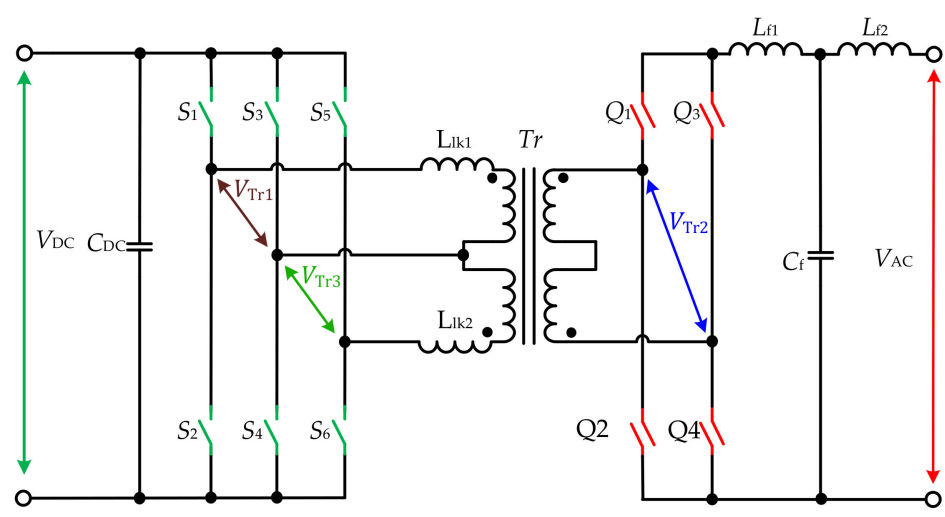

(a)

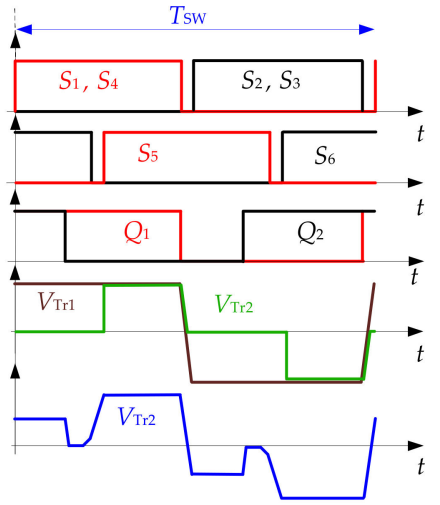

(b)

Figure 8. FB topology with the three switching legs at the DC side (a) and modulation (b) in [79].

\subsubsection{FB Configuration with the Reconfigurable AC Side}

The topology reported in [42,62] is proposed as a unidirectional inverter for the FC applications (Figure 9). It features two transformers and two bidirectional AC side bridges, which can be connected in series or in parallel, providing the universal output. The topology utilizes the SPWM at the DC side, while half of the AC-side switches work with the grid frequency to minimize the switching losses in the converter. The design focuses on the universality of the output voltage and is suitable for both $230 \mathrm{~V}$ and $110 \mathrm{~V}$ and has a high step-up factor to achieve the connection $30-60-\mathrm{V}$ fuel cell and is claimed to be optimal in terms of weight and cost. The authors achieved a peak efficiency of $92.5 \%$ for the proposed concept. The leakage inductances of the transformer are utilized for the soft switching in the semiconductors, but at the same time, the voltage overshoot appears across the AC-side switches. This suggests that the design and optimization of the transformer can be further considered to achieve better efficiency and reduce the stresses in the topology.

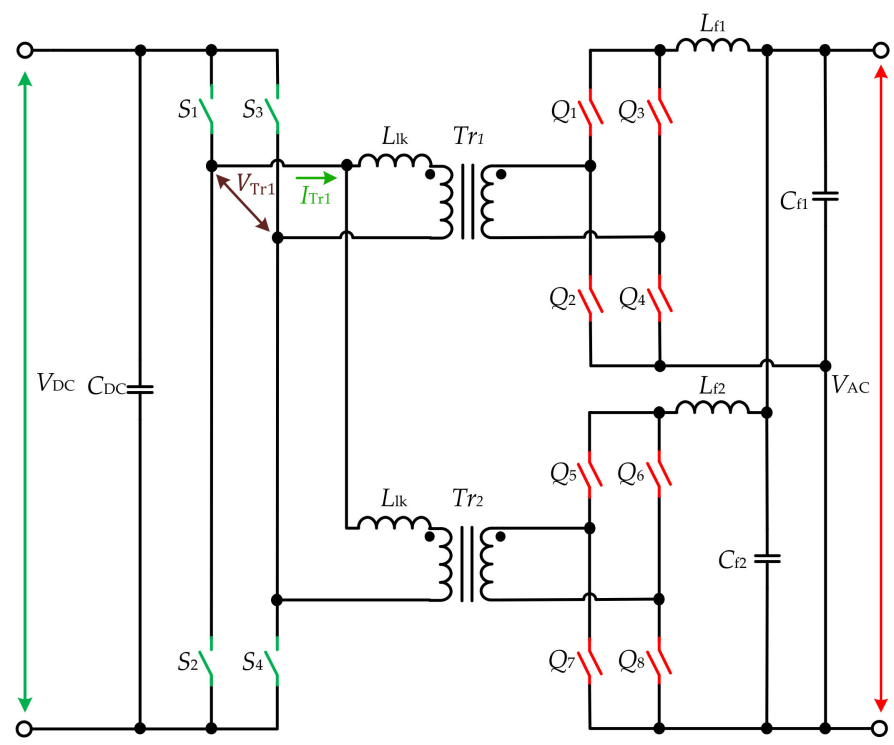

(a)

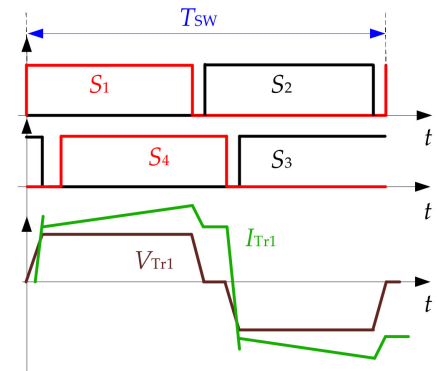

(b)

Figure 9. FB topology with the reconfigurable AC side (a) and modulation (b) shown in [62].

\subsubsection{The FB Configuration with PP at the DC Side}

Figure 10 shows the topology reported in [78] as a unidirectional inverter for renewable energy sources. The topology has two switches at the DC side connected to a central-tapped transformer, forming the PP configuration. The AC side features the FB configuration. The multiple-carrier PWM is 
proposed for this topology. It was suggested that this technique allows reducing the complexity of the control algorithm for the inverter. The topology is suitable for low power applications; the simulation results of the 200-W prototype were shown for 48 VDC input voltage and 127-V RMS output voltage, using a transformer with a turns ratio of 1 to 4.2. An alternative configuration of a bidirectional converter based on the Cuk, SEPIC, Zeta converters is presented in [112] where the 400-W prototype of the SEPIC converter is demonstrated.

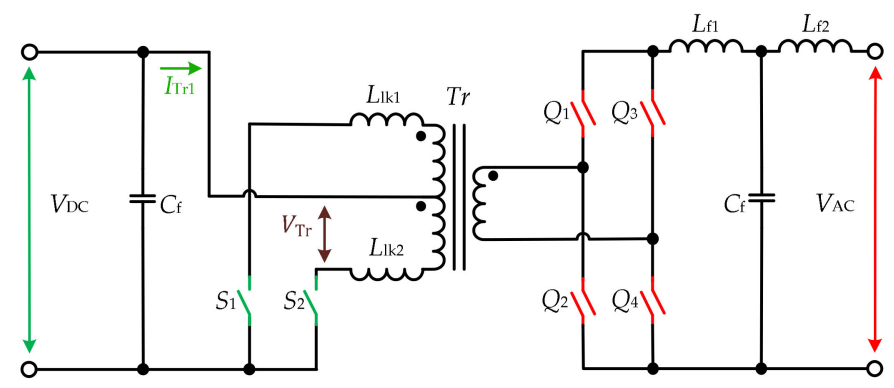

(a)

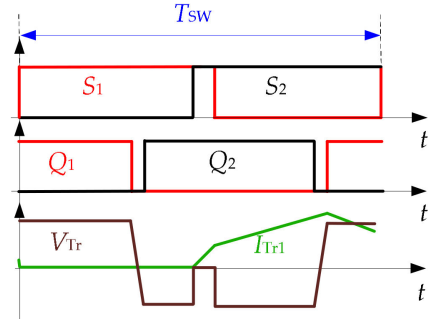

(b)

Figure 10. FB configuration with push-pull (PP) at the DC side (a) and modulation (b) in [78].

In [113], the focus is on a multilevel PP inverter configuration. It utilizes the central tap transformer on both the DC and the AC side and includes an additional bidirectional switch at the AC side. The presence of the additional switch at the AC side and a special modulation strategy based on PSM allows avoiding the current interruption at the AC side, and as a result, voltage overshoots. The paper provides experimental verification on a 162-W prototype with $24-\mathrm{V}$ input DC voltage and $100-\mathrm{V}$ output AC voltage. In addition, the topology is suitable for bidirectional operation.

\subsubsection{HB Configuration}

The topology in Figure 11 [61] is proposed as a unidirectional microinverter for PV applications. It features two transformer windings and two bidirectional switches at the AC side, which work at the line frequency. Thus, the total number of AC-side transistors is reduced by a factor of two when compared to the topology in Figure 6. The DC side, as described, could be configured as a FB, HB or $\mathrm{PP}$, which can allow reducing the total number of the semiconductors even further. SPWM is applied to the DC side semiconductors, realized by a comparison of two $180^{\circ}$ phase-shifted sinewaves with a dual-sided ramp wave. At the AC side, the IGBT switches are utilized with line switching frequency to minimize the losses in the converter. The reported peak efficiency of the $250-\mathrm{W}$ prototype is $94.5 \%$. On the other hand, the ZVS for the DC-side switches has a limited range (occurs at peak power), and the AC-side switches have higher voltage stresses.

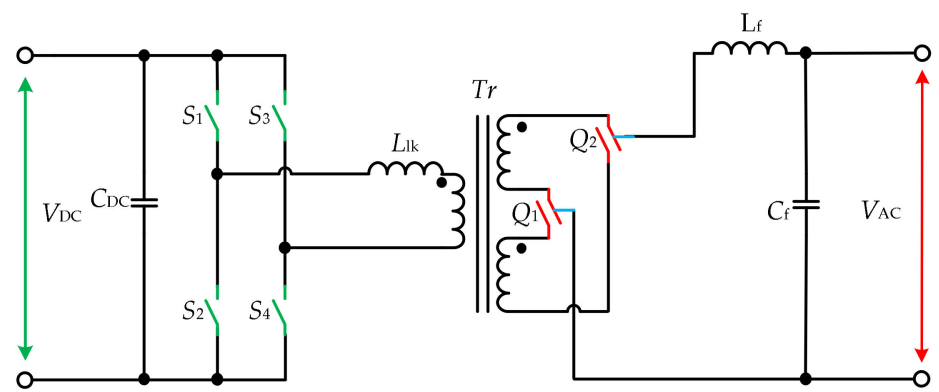

(a)

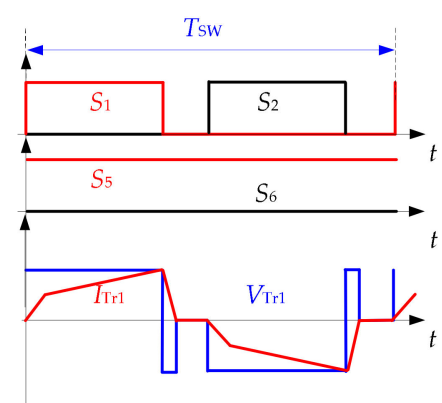

(b)

Figure 11. Half-bridge (HB) configuration (a) and modulation (b) in [61]. 


\subsubsection{LL (dual inductor) HB Configuration}

The dual inductor half-bridge (LL HB) converter type is a popular solution in the DC-DC converters due to the low current ripple. Figure 12 presents the bidirectional converter topology proposed for electric vehicle battery charging applications in $[97,114]$. The original paper describes it as "single-stage bidirectional converter for EV"; however, it will be referred here as LL HB due to the topology configuration. The converter features a full-bridge on the DC side with an additional filter inductor $\mathrm{L}_{\mathrm{DC}}$ and LL-type $\mathrm{HB}$ at the AC side. The converter with the input of 120-V RMS AC is connected to a 220-336 VDC battery through a converter that has a high-frequency transformer with a turn ratio of 0.5 . In the rectifier mode, the converter operates as a two-phase boost converter, while in the inverter mode, it acts similar to a FB converter with the current doubler rectifier the output voltage regulation is achieved by PSM. The converter features reduced current ripple due to the presence of two inductances at the AC side, allowing the ZCS to be achieved at the AC side, and ZVS turn-on at the DC side. Moreover, it can operate in four quadrants with active and reactive power regulation for both directions of the power flow. In the inverter mode, the PSM is implemented for the DC-side switches, while the AC-side switches are continuously on or off depending on the polarity of the grid voltage. Peak efficiency of $96.5 \%$ at full power is reported for the $1.5-\mathrm{kW}$ prototype. At the same time, the topology requires an additional inductor, the voltage stress on the switches is increased, and it is estimated to have substantial energy circulation at partial load. The simulation results of the three-phase system shown in [98].

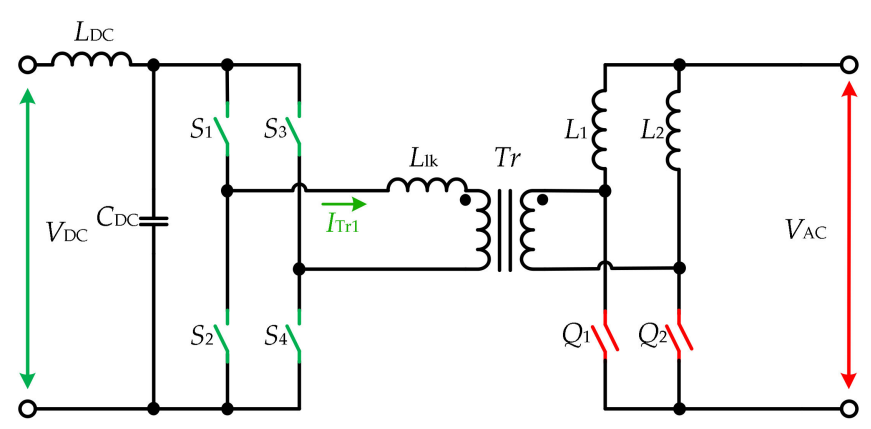

(a)

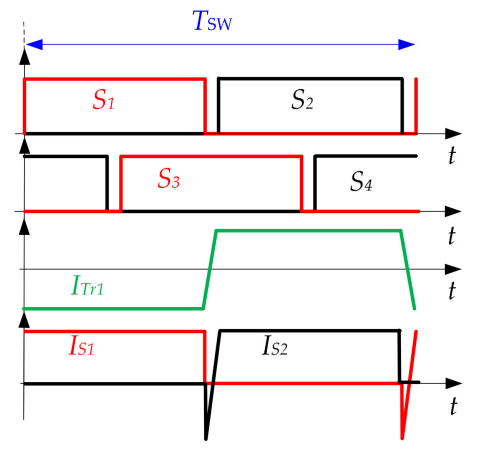

(b)

Figure 12. Single-stage bidirectional converter for EV (LL HB) configuration (a) and modulation (b) proposed in [114].

\subsection{Non-Resonant PP Topologies}

\subsubsection{PP Configuration}

The topology in Figure 13a was introduced in [103] for the UPS. The topology utilizes the central tapped transformer and two bidirectional switches at the AC side, while the DC side has a FB inverter. In [104], the converter was controlled with SPWM modulation at the DC side. In [99], an improved modulation method is introduced to handle the non-unity power factor without snubbers. A novel digital control using the bipolar double modulation wave was addressed in [108], which is shown in Figure 13b. The sinusoidal output voltage is formed by AC-side semiconductors using PSM. It allows achieving the ZVS turn-on on the DC side, and the ZVS turn-off at the AC side. The experimental verification of the topology was presented using an experimental 250-W prototype with and 46-V output voltage. In [96], the topology with four additional snubber capacitors for switches S1-S4 is presented. The aim is to achieve the ZVS and ZCS in all semiconductor devices using PSM. The experimental waveforms of the prototype with $24-\mathrm{V}$ input voltage and transformer 1:2.74 are shown. Another version of the PSM is used in [115] to achieve the ZVS in the topology, which was confirmed with a 1-kW experimental setup. Reference [116] presents the unidirectional converter for PV application, which utilizes the additional two inductors at the AC side. 


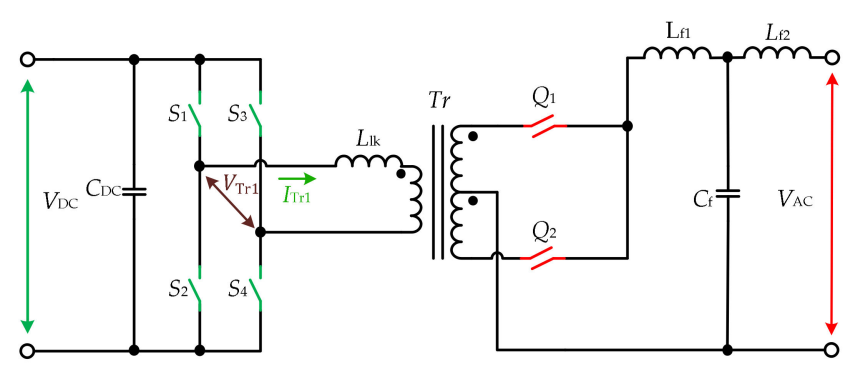

(a)

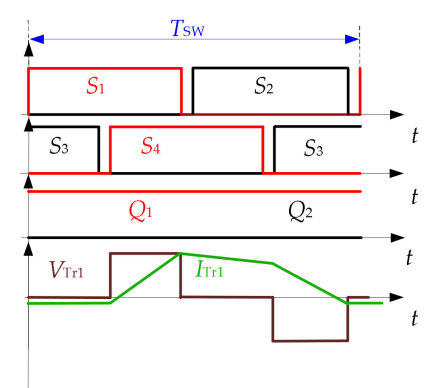

(b)

Figure 13. PP configuration (a) and modulation (b) in [117].

The three-phase system for the three-phase drive reported in [67] is shown in Figure 14. The topology has three parallel ports to support bidirectional operation with the source commutation method. The topology is also suitable for the UPS, PV and battery storage systems.

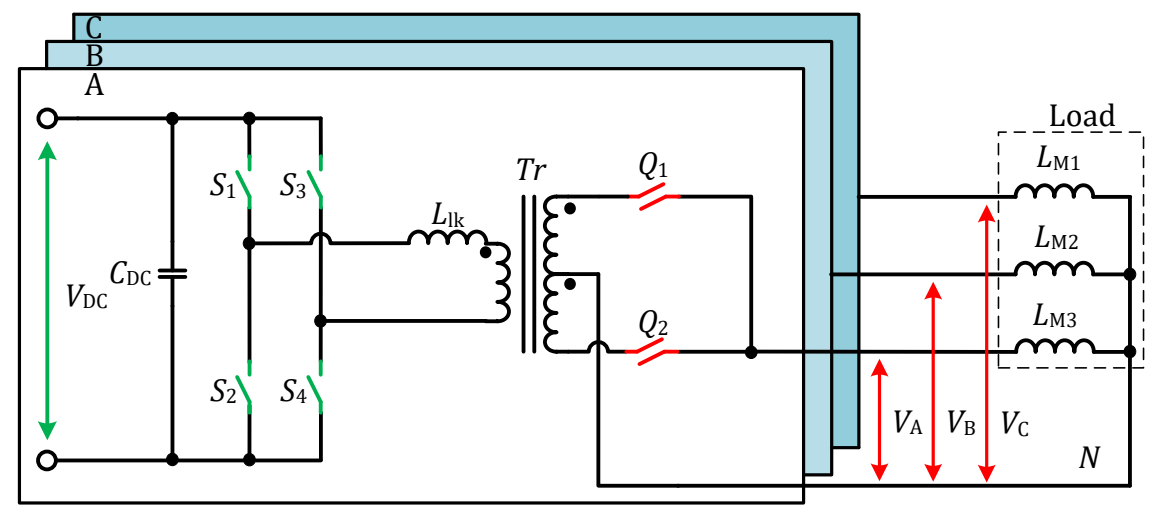

Figure 14. The three-phase PP configuration.

A novel ZVS approach for the flyback-PP inverter for low-power PV application is presented in [118]. The AC part of the topology is similar to that in Figure 13, while the input DC bridge is replaced by one switch, forming the flyback configuration. The soft-switching on the DC-side switch is achieved by additional circulating energy from the grid filter capacitor. To optimize this reactive current, the variable frequency control was proposed. Experimental results confirm the feasibility and show $94.5 \%$ peak efficiency of the system.

\subsubsection{PP Configuration with voltage clamper}

The topology of the bidirectional inverter presented in Figure 15 was introduced in [82] for the UPS system. The topology configuration consists of FB on the DC side, a central-tapped transformer with two bidirectional switches on the AC side and an additional clamping circuit. This active clamping circuit is proposed for the minimization of the voltage overshoots. It consists of four switches, which form the bridge, two diodes and clamp capacitor (the configuration without the capacitor is also possible [82]). The energy stored in the capacitor is transferred back to the DC source and reutilized. The SPWM is used to control the DC side, while AC-side switches are rectifying. The drawbacks could be attributed to a limited ZVS range, extra two diodes and a capacitor when compared to the FB solution without a snubber circuit.

Other approaches to control the configuration of the bridge clamp are reported in $[75,81,83,119]$. In $[83,84]$, a detailed analysis of the operation of the bidirectional topology and clamping circuits is given. The experimental waveforms of the $500-\mathrm{W}$ prototype with efficiency around $90 \%$ are provided, and the converter is proposed for renewable, naval and aerospace applications. In [75,119], the topology was proposed for the low-power audio amplifier. The operation principle of the uni- and bipolar PSM 
strategy is described and verified. In [81], an alternative bipolar PWM is proposed. It is suggested to allow achieving lower voltage distortion of the output compared to the unipolar PWM.

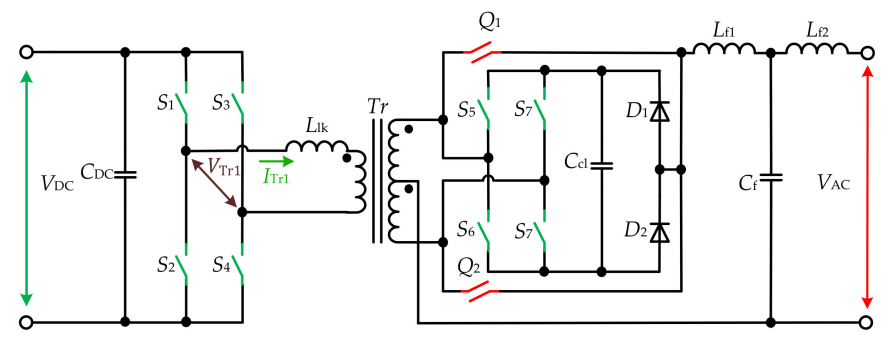

(a)

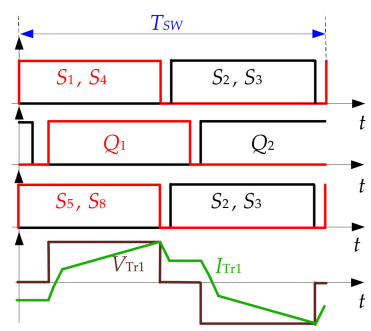

(b)

Figure 15. PP configuration with voltage clamper (a) and modulation (b) in [83].

\subsubsection{PP Configuration with the Current Clamping Switch}

The topology presented in Figure 16 [120-122] uses a standard full-bridge at the DC side. However, the AC side is realized with a center-tapped transformer and three bidirectional switches. In the original paper, the AC side structure was described as "three bidirectional switching arms" and referred to as PP configuration with the current clamping switch in this review due to the topology configuration. The DC side FB converts the DC voltage to the HF AC square wave. On the AC side, the switching signals are obtained by comparing the modulating waveform with the sawtooth carrier waveform. The bidirectional switch Q3 connected to the center tap is turned on when both Q1 and Q2 are in the off-state to provide a freewheeling path for the output current. The additional overlap is added to realize the natural commutation of semiconductor devices and reduce overvoltage. The converter realizes ZVS and ZCS for the semiconductor switches and requires three bidirectional switches instead of four for the FB-FB topology. The bidirectional operation capability is reported, but not addressed.

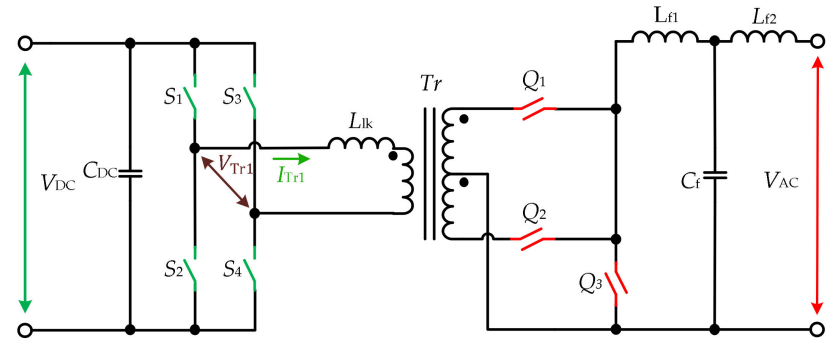

(a)

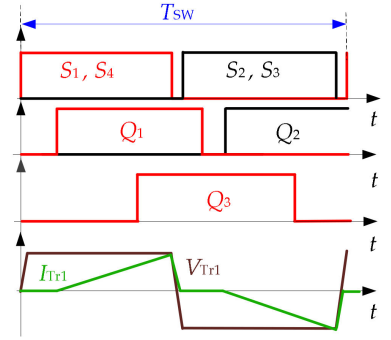

(b)

Figure 16. PP configuration with the current clamping switch (a) and modulation (b) in [121].

Other versions of the topology for the bidirectional battery charger are reported in [85]. It utilizes three bidirectional switches with regenerative flyback clamp circuit at the AC side, while the DC side is FB. The presence of the clamping circuit allows the reduction of the voltage overshoot in $\mathrm{AC}$ and also helps to achieve the ZCS in the AC switches. The energy stored in the clamp capacitor is returned to the DC side and reused. The unipolar SPWM modulation strategy is used for both power transfer directions. The concept is verified with a $1.5-\mathrm{kW}$ prototype with a $96 \%$ peak efficiency conversion from $300-\mathrm{V}$ battery to the $120-\mathrm{V}$ RMS grid.

\subsection{Resonant PP Topologies}

PP Configuration with a Parallel Resonant Tank at the DC Side

In [80], the sine AM modulation (SAM) was proposed as an alternative approach for the conventional PWM with varied duty cycles. The topology consists of the PP configuration at the AC side and the FB with the parallel resonant tank at the DC side (Figure 17). The resonant tank 
is connected between the middle point of the bridge legs and the middle point of the input voltage source. The bridge leg is operated with a varying duty cycle and a constant phase shift. The switching frequency of the converter is slightly higher than the resonant to extend the load independence and enable ZVS in the semiconductors.

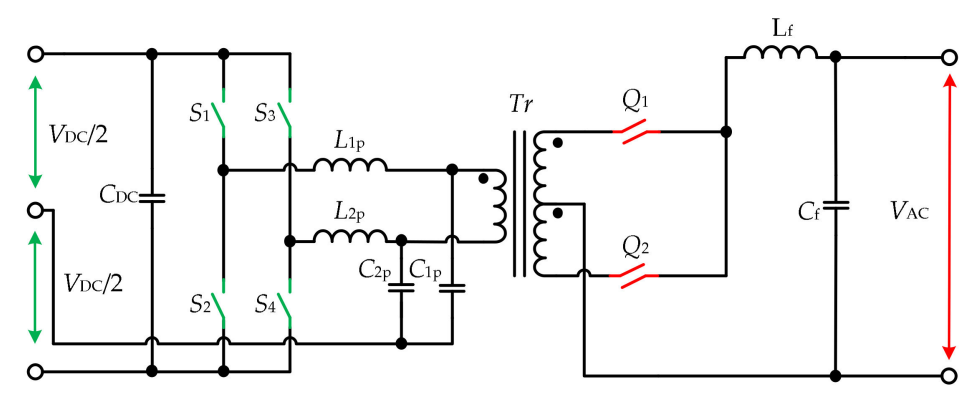

Figure 17. PP configuration with a parallel resonant tank at the DC side.

The results are verified with a simulation model of a 2-kW converter. The converters with the parallel and with the series resonant tank were analyzed for the connection 450-V DC source with the utility grid. It is shown that the topology in Figure 17 has lower efficiency than the voltage source version on the topology with the series resonant tank, which will be described later.

The resonant inverter based on the topology from Figure 13 was introduced in $[123,124]$ and described in more detail in [125]. It uses a resonant capacitor in series to the leakage inductance. The topology is proposed for the UPS application and features a lower output voltage ripple. It allows soft switching in the semiconductors using the SPWM modulation applied for FB thanks to the presence of the resonant tank at the DC side. The AC-side switches are forming, working at the grid AC waveforms.

\section{VSI Based Topologies}

This section presents the topologies of the isolated matrix inverters with a grid side switching stage based on the VSI. The subsections are organized according to the fourth hierarchical level of the classification from Figure 5.

\subsection{Non-Resonant Bridge Topologies}

\subsubsection{FB Configuration}

Many different configurations of the VSI-based converters have been reported (also known as a dual active bridge) $[55,56,77,125-136]$. In [105], the topology consists of two voltage source full-bridges, as shown in Figure 18. The advanced modulation strategy proposed is based on the triple-phase shift. The method allows for achieving soft-switching in a wide range of voltage and load. The experimental $300-\mathrm{W}$ prototype microinverter for the integration of the low-voltage DC source to the AC confirmed theoretical descriptions in that work. The authors proposed the extension of this configuration for the 3-port converter. In this case, in the first port is the PV module, the second-a battery and the third the AC grid. The connection of this part was made through the three-winding transformer. In general, the topology is suitable for different voltage levels, but the design of the high-frequency transformer can be a challenging part.

For the high-power applications, the VSI three-phase topologies can also be utilized (Figure 19). References [101,106,126-128] present PV inverter, battery storage and EV charger systems. In those systems, the PSM modulation strategy was used and is extended for the three-phase implementation. In [127], the three-port three-phase converter was proposed for interfacing between the renewable source, battery and the utility grid controlled by PSM. 


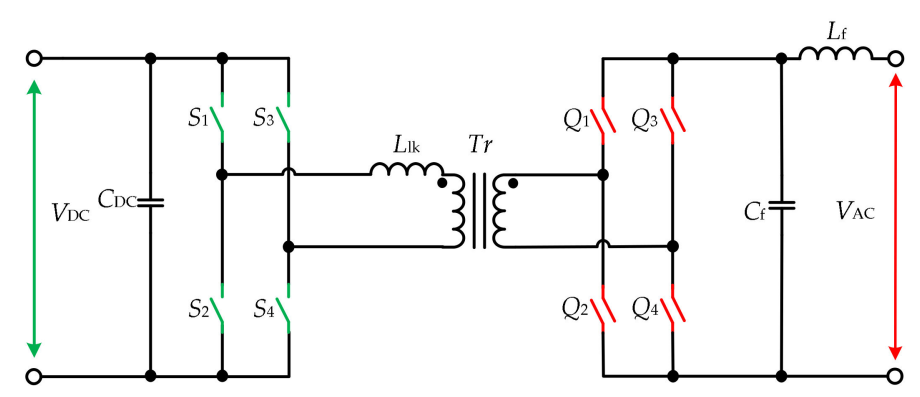

Figure 18. FB configuration.

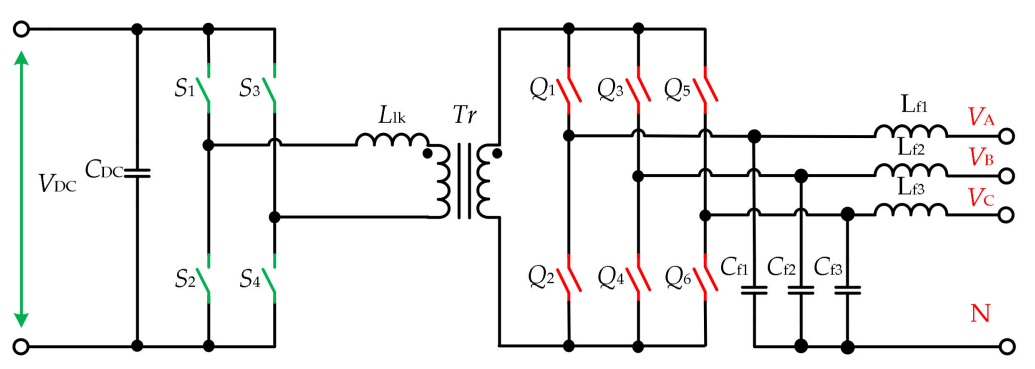

Figure 19. Three-phase FB configuration.

\subsubsection{HB Configuration}

The bidirectional converter in Figure 20 is proposed for electric vehicle charging with power factor correction functionality $[66,100]$. The topology features a voltage source converter with two bidirectional switches and two capacitors on the AC side. At the DC side, a standard FB is applied. Additional inductors are supplied to both sides of the converter to reduce the current ripple. Thus, the DC side has the same number of switches, while the AC side has a twice reduced number of switches when compared to the FB-FB topology. The converter control algorithm is based on a general trapezoidal current mode modulation of the voltage source DC-DC converter and is operating with a combined phase shift and frequency modulation for shaping the transformer leakage inductance current. This method is used to transfer high power with small peak current and achieve ZVS at any time interval. Peak efficiency of $95 \%$ is obtained at half load for a $3.3-\mathrm{kW}$ prototype and is claimed to potentially reach $97 \%$, the value of efficiency depending on the battery voltage. At the same time, the converter requires rather complex multi-mode control with lookup tables to guarantee ZVS within the full range of operating conditions. The wide ratio of operating frequencies (1:6) imposes additional requirements on the design of passive elements. In practical systems, the efficiency is limited since certain minimum commutation current is required to guarantee ZVS over the whole AC grid cycle. The aim was to design a converter suitable for the medium/high voltage battery energy system. In this case, the converter submodules are connected per phase in series and share one filter inductance.

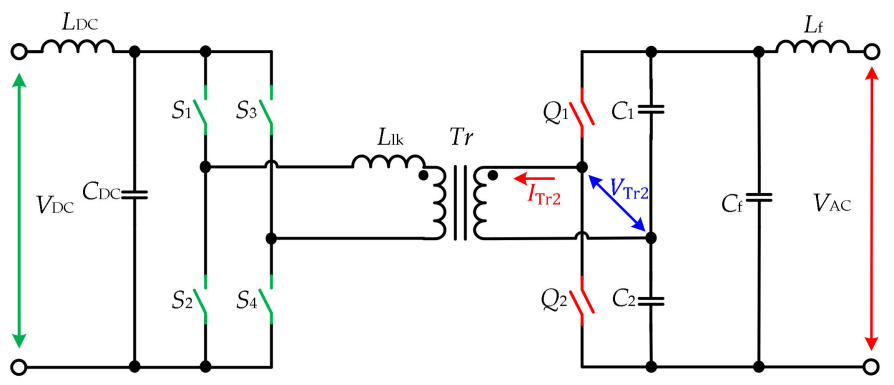

(a)

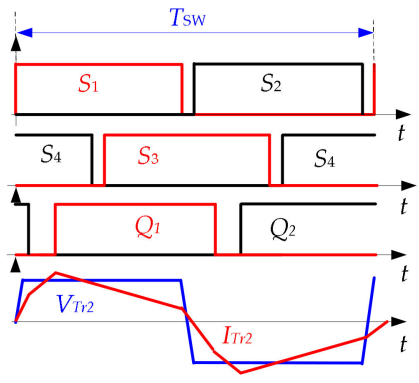

(b)

Figure 20. HB configuration (a) and modulation (b) in [66]. 
In [128], a 3-phase HB configuration of the VSI is proposed for the bidirectional conversion between the renewable source and the grid using the novel PSM modulation for the converter.

\subsection{Resonant Bridge Topologies}

\subsubsection{FB Configuration with the Series Resonant Tank}

Application of the series resonant FB inverter is shown in Figure 21 [60,129]. A converter for the photovoltaic application was proposed and verified in [60]. The converter consists of two full-bridges and transformer leakage inductance with the resonance capacitor forming the series resonant tank. As a result, the DC side PSM strategy and resonant tank allow achieving the soft switching in all devices. In [129], the topology was reported as the bidirectional charger for the electric vehicle. The converter operation is similar to that previously discussed, but it is shown for both power flow directions: from the grid to electric vehicle and back.

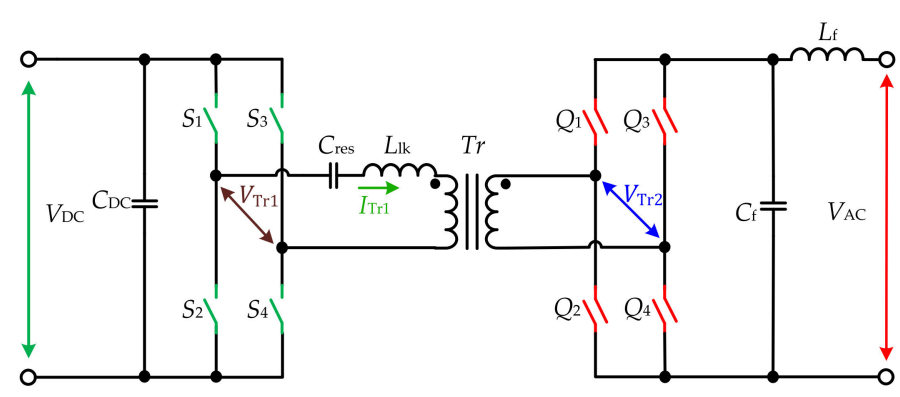

(a)

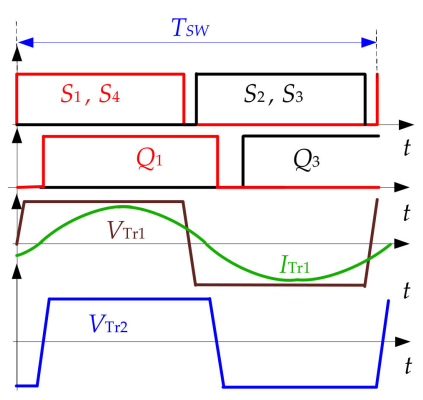

(b)

Figure 21. FB configuration with the series resonant tank (a) and modulation (b) in [60].

\subsubsection{FB Configuration with the Series Resonant Tank and HB at the DC Side}

The topology in Figure 22 is a FB topology with the series resonant tank and HB DC side, which is described in detail in [130] and proposed for UPS. The inverter uses the modulation of the DC side and allows achieving quasi ZCS on the switches. A small-scale converter prototype was shown, along with experimental waveforms with linear and nonlinear loads. As the drawback of the topology is that the current in the DC-side switches is higher compared to the FB-FB converter, the topology is more suitable for low-power applications.

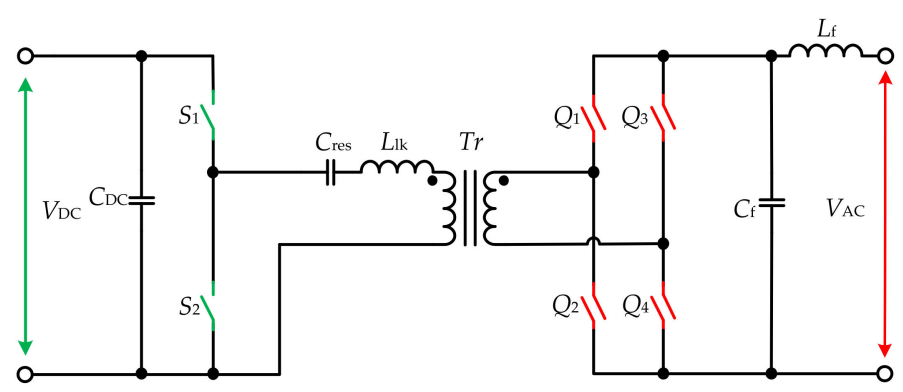

Figure 22. FB configuration with the series resonant tank and HB at the DC side.

\subsubsection{HB Configuration with the Series Resonant Tank}

The circuit (Figure 23) for a PV microinverter is presented in [86]. The topology is based on a series resonant inverter at the DC side and HB voltage-doubler configuration at the AC side. The special dual-phase shift modulation strategy for the topology allows achieving ZVS for all semiconductors. The experimental prototype for the integration of the low-voltage DC to AC grid with almost $96 \%$ CEC efficiency was shown. 


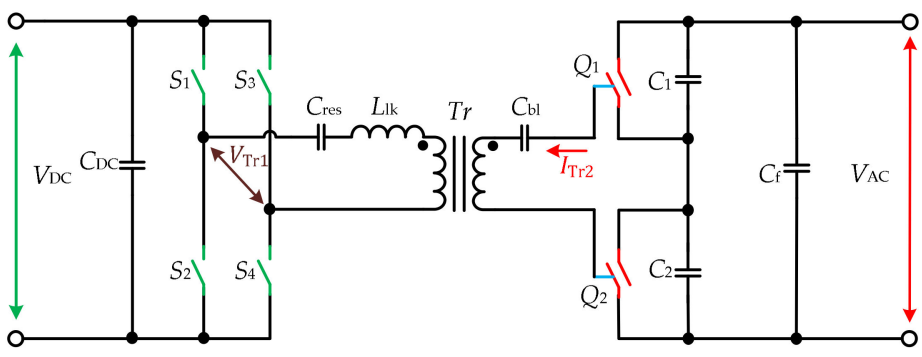

(a)

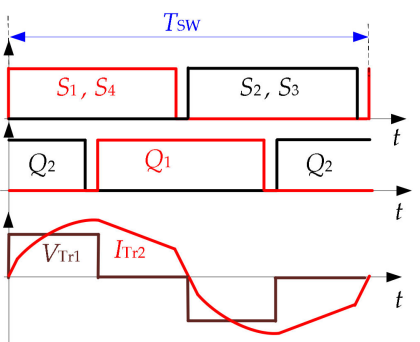

(b)

Figure 23. HB with the series resonant tank (a) and modulation (b) in [86].

An alternative version of the topology is addressed in [102]. The topology has similarity with Figure 23, but does not contain the resonant tank and blocking capacitor. Instead, the additional snubber capacitor at the AC side is used, which provides the current path and no overshoot from leakage energy is present at the AC-side switches. The topology was built in gallium nitride (GaN) switches and used the dual-phase shift with variable frequency modulation to achieve ZVS. The hardware prototype is shown to have the rectification from $230-\mathrm{V}$ AC to $48-\mathrm{V}$ DC. The topology is also capable of DC AC conversion; however, this operation is not described.

\subsubsection{HB Configuration with the Series Resonant Tank and HB at the DC Side}

The converter in Figure 24 is recommended for an electric vehicle battery charger $[107,131]$. The topology utilizes resonant $\mathrm{HB}$ with an active shunt circuit, which absorbs the current ripple at the DC side. In addition, at the AC side, the HB configuration is used. The presence of the active filter at the DC side allows the reduction of the double grid frequency ripple in the current and reduces the overheating of the battery. A special four-part control PSM strategy is proposed for the system, which allows operation with different power ranges and achieving ZVS for all semiconductors.

In [132], a variation of this topology is suggested for the on-board electric vehicle charger. This converter includes the resonant tank and additional boost-buck stage for the additional gain on the DC side, while the AC side is an HB. The topology does not require a bulky DC link between the boost-buck stage and the inverter stage. The authors proposed the harmonic modulation strategy, which allows improving the power factor in DCM. The 3-kW experimental bidirectional prototype was built with an efficiency of $93 \%$ at rated power.

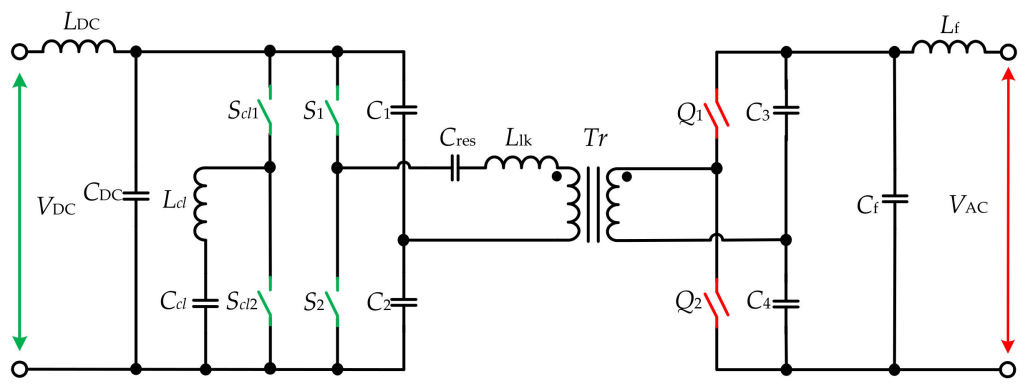

Figure 24. HB configuration with the series resonant tank and HB at the DC side for the electric vehicle battery charger.

\subsection{Resonant PP Topologies}

PP Configuration with the Series Resonant Tank

In [80], a topology consisting of the PP configuration at the AC side and the FB with the series resonant tank at the DC side is described (Figure 25). The series resonant tank is connected between the 
middle point of the bridge legs, transformer AC sidewinding and the middle point of the input voltage source. The SAM modulation for the DC side semiconductors is presented. The 2-kW simulation model of the inverter was made for the connection 450-V DC source with the utility grid. Resulting from the comparative analysis in the paper, this topology has lower energy circulation, but higher THD, particularly at low power when compared to the CSI version of the topology in Figure 17 with the parallel resonant tank.

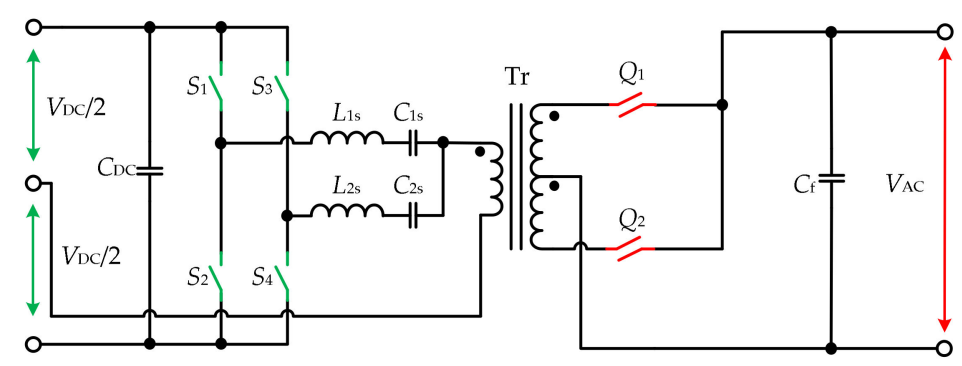

Figure 25. PP configuration with the series resonant tank.

\section{Discussion and Future Trends}

\subsection{Critical Overview}

An important contribution of this work is that it establishes the isolated matrix inverters as a class of true single-stage topologies separate from the quasi-single-stage class. This division is important as the isolated matrix inverters can provide a wider range of features. Besides being the true single-stage solution, these inverters have the following advantages:

- they could provide the soft switching in all semiconductor switches using special modulation strategies;

- in the voltage step-up applications, they avoid unreliable high-voltage electrolytic capacitor(s) with a limited lifetime and utilize much more reliable low-voltage electrolytic capacitor(s) for the filtering of 100/120 Hz voltage ripple;

- their cost can be reduced considerably with the implementation of emerging bidirectional monolithic semiconductors or the ones with the reverse blocking capability.

The main disadvantage of the isolated matrix inverters compared to their two-stage counterparts is their relatively narrow input DC voltage range, which limits their applicability in demanding applications. Other disadvantages can be associated with the limitations of the general level of technologies rather than the concept itself. For example, the level of control complexity was not compatible with the existing technology when the first topologies appeared around 30 years ago. This was holding back the adoption of these inverters for some time. Nowadays, available low-cost microcontrollers can realize control of the isolated matrix inverters. Moreover, recent appearance of numerous two- and quasi-single-stage solutions had gained popularity despite even more complicated control. Therefore, the isolated matrix inverters can also be accepted by industry if sufficient awareness is raised.

Among the two main families of topologies, the CSI based isolated matrix inverters attracted more attention of researchers compared to the VSI based counterparts, which resulted in twice as many topologies developed. It can be attributed to their use of conventional LC and LCL filters, which makes them a logical replacement of two-stage counterparts with the same filter type. In both groups, around half of the reported topologies were developed in the last five years, which shows high activity in this field of research. Nevertheless, both converter groups demonstrate efficiency growth from roughly $90 \%$ in early works up to $96 \%$ in later developments. It is worth mentioning that the CSI based topologies have demonstrated high efficiency in a wider range of applications. Most of the research was dedicated to the bridge type isolated matrix inverters, where the most prominent example is the single-phase 
full-bridge implementation. The widest number of modulations was applied to full-bridge topologies as they provide the widest range of the possible switching states and thus ensure the best controllability. In addition, they were justified for most of the possible applications. The push-pull type isolated matrix inverters are the second most used type. They allow reduction of the amount of the active component and, in some cases, can avoid auxiliary clamping circuits. However, the utilization of an auxiliary clamping circuit could result in the number of the switches lower than that in the full-bridge type counterparts. Push-pull type isolated matrix inverters can be more beneficial in low-power applications. For example, they were mostly proposed for the PV microinverter and chargers with the power rating below two kilowatts. Meanwhile, three-phase implementations are feasible for both full-bridge and push-pull type inverters. They can be useful in high-power applications rated for over one kilowatt, which is justified by application examples for the high voltage BESS and PV inverters. Among possible derivations of the bridge type topologies, the LL HB type inverters were used in battery chargers due to their very low current ripple and simple modulation. The other examples of the half-bridge type inverters were mostly used to reduce the number of active semiconductors and associated costs.

The isolated matrix inverters reported and analyzed in the review are typically two-level topologies. The main properties and features of two-stage, quasi-single-stage and isolated matrix inverters are summarized in Table 1.

Table 1. Evaluative comparison of various isolated inverter topologies.

\begin{tabular}{cccccc}
\hline Topology & DC Link & $\begin{array}{c}\text { Number of } \\
\text { Conversion Stages }\end{array}$ & $\begin{array}{c}\text { Soft Switching in } \\
\text { Transistors }\end{array}$ & $\begin{array}{c}\text { Use of } \\
\text { Bidirectional } \\
\text { Switches }\end{array}$ & $\begin{array}{c}\text { DC Voltage } \\
\text { Regulation Range }\end{array}$ \\
\hline Two-stage & Bulky & 2 stages & DC/DC-soft & No & Moderate-wide \\
$\begin{array}{c}\text { Duasi-single- stage } \\
\text { Single-stage }\end{array}$ & $\begin{array}{c}\text { Small (optional) } \\
\text { Absent }\end{array}$ & 1 stage & Soft & No & Limited \\
\hline
\end{tabular}

\subsection{Design Challenges}

During the 30-year history of the research and developments of the isolated matrix inverters, numerous topologies were proposed. In the 1990s, the proposed topologies were based on thyristors and IGBT devices, with the switching frequencies up to 10-15 kHz. Their demonstrated efficiency usually did not exceed $90 \%$. The main research trends in the field were dedicated to topological aspects, the optimization of the components (especially AC side filters), optimization and improvements of the system efficiency, improvements of the rectifier mode operation capability. In addition, research directed toward synthesis of new modulation techniques that either utilize parasitic components for soft switching or limit their influence on converter operation as some of them are unavoidable, e.g., leakage inductance, the capacitance of the transformer, the capacitance of the switches and PCB. These improvements together with development in component semiconductor and magnetic material technologies enabled the use of significantly increased switching frequencies (up to $200 \mathrm{kHz}$ ), improved power density, resulting from the reduced size of the magnetic components. Moreover, this allowed an increase in the efficiency to $96 \%$, which now is comparable and sometimes superior to the two-stage conversion systems. Nevertheless, various design challenges related to isolated matrix converters still exist, the majority pertaining to optimization of operating conditions for semiconductors and transformer design aspects.

\subsubsection{Semiconductors}

The isolated matrix inverter technology evolved together with power semiconductor devices, moving from Si thyristor, IGBTs and MOSFETs to WBG semiconductors. New generation power semiconductor devices, such as GaN HEMTs, SiC MOSFETs and Schottky diodes, enable substantial reduction of the losses associated with transistor switching and diode reverse recovery, allowing much higher switching frequencies to be used. On the other hand, the use of bidirectional switches and high 
number of discrete semiconductor components could discourage industrial adoption of the isolated matrix inverters. However, this number is in fact similar to that of industry-approved two-stage and quasi-single-stage solutions. Moreover, a new impulse for industrialization can be given by the recent developments in monolithic reverse-blocking and bidirectional semiconductor devices that have been reported for $\mathrm{Si}, \mathrm{SiC}$ and $\mathrm{GaN}$ technologies [137-142]. This technology can make the isolated matrix inverters attractive to the industry by reducing the number of discrete devices by up to twofold at the AC side.

\subsubsection{Isolation Transformer}

The use of the HF transformers imposes challenges on the scalability of the isolated matrix inverters. The limiting factors are core losses (losses from eddy current and magnetic losses), high-frequency losses (skin and proximity effects and winding losses in the high current application), parasitic resonances (usually between the capacitance and leakage inductance of the transformer, but the topology has some influence on it) [143]. Depending on the operating switching frequency, the impact of the total transformer losses in the total power loss will be different. For switching frequencies of up to a few dozen $\mathrm{kHz}$, GTOs and IGBTs are commonly utilized, which results in the dominant impact of their switching losses on the overall efficiency. At higher switching frequencies, where the implementation of $\mathrm{Si}, \mathrm{SiC}$ and $\mathrm{GaN}$ devices is favored, an increased impact of the transformer losses is expected. The soft switching range in the CSI based galvanically isolated matrix inverters is usually determined by the values of the transformer leakage inductance and parasitic capacitance. In the VSI based solutions, the value of the leakage inductance has an effect on regulation near the voltage zero-crossing point. The transformer power and turns ratio significantly influence the values of the parasitic parameters and, consequently, limit the overall efficiency. The scaling of the transformer is mostly defined by the required power rating and power density. A compact design usually requires increasing the working frequency but results in lower efficiencies. Finding the tradeoff between the target power density and efficiency of an inverter may require an iterative search for the optimal topology as a compact transformer design could result in such a combination of switching frequency and the leakage inductance that may limit the feasibility of some of the topologies. The isolated matrix converter prototypes reported in the literature have been mainly using ferrite RM cores for powers $<1 \mathrm{~kW}$ and toroid or E cores for powers over one kilowatt. Improved transformer characteristics may be obtained with amorphous and nanocrystalline magnetic materials, which can result in core losses reduction by up to $70 \%$ than conventional solutions $[144,145]$.

\subsection{Application Examples}

The practical realization of the isolated matrix inverters for a target application depends on the engineering design and limitations of existing technologies of semiconductor and magnetic components. Hence, it is important to compile a comprehensive list of application examples with key operating parameters to provide an initial suggestion regarding the suitability of a topology to a certain application. Therefore, application examples of the isolated matrix inverters were summarized in Table 2 to provide a critical view of the practical value of each of the roughly thirty topologies and support claims of this section. The comparison considers the number of switches on both sides separately, transformer turns ratio, maximum power and reported experimental efficiency, input and output voltage level or range, switching frequency and the used modulation technique. As can be seen from the table, the technology of isolated matrix inverters is a versatile solution that suits different applications. 
Table 2. Summary of the existing solutions of the isolated matrix inverters.

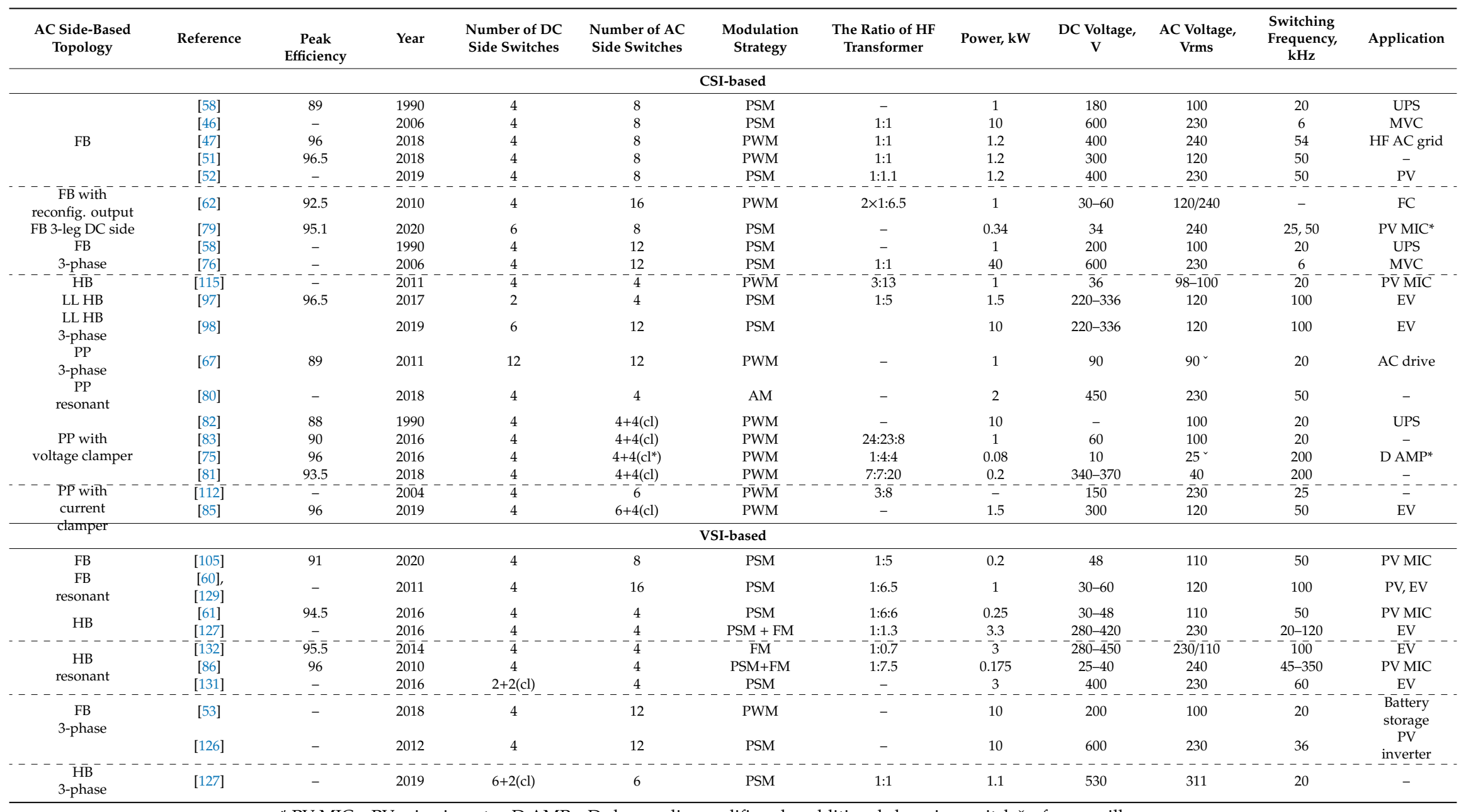

* PV MIC—PV microinverter, D AMP—D class audio amplifier, cl—additional clamping switch ^—from oscillograms 
It is worth mentioning that the compiled list of application examples is reflecting the current state-of-the-art and does not limit future applications. It could be expected that they can be used in more electric aircraft [146], where conventional matrix converters were justified. Currently, only VSI based solutions were adopted by industry for PV microinverter applications. However, in the last few years, early attempts of industrialization of the CSI based isolated matrix inverters have emerged. For example, "ACDC cube" project of INESC TEC in Portugal [147]. More commercial products employing CSI based solutions can be expected in the future. This paper aims to facilitate its wider industrial acceptance.

\section{Conclusions}

This paper provides a fresh view of existing galvanically isolated inverters and establishes their division into three main classes: two-stage, quasi-single-stage and single-stage. The superiority of features provided by the single-stage solutions makes the isolated matrix inverters a promising solution. Currently, over thirty topologies have been reported where two-thirds belong to the group based on current-source inverters. They have attracted more research interest as the logical replacement of two-stage solutions with the same LC or LCL grid side filter. Nevertheless, the VSI-based topologies can demonstrate equally high efficiencies of $96 \%$ and have been industrialized already in the PV microinverter applications. Regardless of the basic inverter topology, full-bridge solutions are the most popular due to their high control and modulation flexibility. This trend is expected to continue in the future, but push-pull converters with voltage or current clamping will also gain momentum in development.

Vast majority of the topologies presented in this review were found to use either PWM or PSM. The CSI-based isolated matrix inverters are using PWM twice as often as PSM. However, both modulations have shown the capability of achieving $96.5 \%$ efficiency under similar operation parameters. At the same time, the voltage source-based topologies are using PSM three times more often than PWM. Here, PSM showed better efficiency levels than in the case of PWM mainly due to utilization of more than one phase shift. More sophisticated methods additionally apply FM to obtain even better characteristics.

The suggested range of existing applications is wide, but most of the topologies were proposed for photovoltaic, battery energy storage, electric vehicle charging and uninterruptible power supply applications. Less common applications include D class audio amplifiers, adjustable speed drives, medium voltage converters, fuel cells and local high-frequency AC grid forming. This proves the versatility of the isolated matrix inverters and shows that much wider application areas can be expected to appear in the near future.

Future research is expected to be focused on the development of new modulation techniques (mostly based on PWM and PSM), voltage range extension at the DC side, optimization of component sizes (especially AC side filter), experimental validation of benefits of the isolated matrix inverters in new applications (e.g., more electric aircraft, electric transportation, grid-connected rectifiers, etc.). Another important research topic relevant to industrial acceptance lies in the accumulation of additional knowledge in control and regulation methods for these inverters. For example, it is required to investigate the use of isolated matrix inverters in reactive power regulation, power quality and grid code compatibility potential, including fault ride-through capabilities.

Author Contributions: Conceptualization, O.K. and A.B.; writing-original draft preparation, O.K. and A.B.; writing-review and editing, D.V. and A.C.; supervision, A.B and D.V.; funding acquisition, A.B and D.V. All authors have read and agreed to the published version of the manuscript.

Funding: The preparing of this publication was supported in part by the EEA/Norway Financial Mechanism 2014-2021 under Grant EMP474 and in part by the Estonian Centre of Excellence in Zero Energy and Resource Efficient Smart Buildings and Districts, ZEBE, grant 2014-2020.4.01.15-0016 funded by the European Regional Development Fund.

Conflicts of Interest: The authors declare no conflict of interest. 


\section{References}

1. Child, M.; Koskinen, O.; Linnanen, L.; Breyer, C. Sustainability guardrails for energy scenarios of the global energy transition. Renew. Sustain. Energy Rev. 2018, 91, 321-334. [CrossRef]

2. O'Neill, B.C.; Oppenheimer, M. CLIMATE CHANGE: Dangerous Climate Impacts and the Kyoto Protocol. Science 2002, 296, 1971-1972. [CrossRef] [PubMed]

3. Rosen, A.M. The Wrong Solution at the Right Time: The Failure of the Kyoto Protocol on Climate Change. Politics Policy 2015, 43, 30-58. [CrossRef]

4. Savaresi, A. The Paris Agreement: A new beginning? J. Energy Nat. Resour. Law 2016, 34, 16-26. [CrossRef]

5. Verbic, M.; Filipović, S.; Radovanović, M. Electricity prices and energy intensity in Europe. Util. Policy 2017, 47, 58-68. [CrossRef]

6. Rockström, J.; Gaffney, O.; Rogelj, J.; Meinshausen, M.; Nakicenovic, N.; Schellnhuber, H.J. A roadmap for rapid decarbonization. Science 2017, 355, 1269-1271. [CrossRef]

7. Al Irsyad, M.I.; Halog, A.; Nepal, R. Renewable energy projections for climate change mitigation: An analysis of uncertainty and errors. Renew. Energy 2019, 130, 536-546. [CrossRef]

8. IRENA. Global Energy Transformation: A Roadmap to 2050, 2019 ed.; International Renewable Energy Agency: Abu Dhabi, UAE, 2019; ISBN 978-92-9260-121-8.

9. IRENA. Electrification with Renewables: Driving the Transformation of Energy Services; International Renewable Energy Agency: Abu Dhabi, UAE, 2019; ISBN 97.

10. Kassakian, J.G.; Jahns, T.M. Evolving and Emerging Applications of Power Electronics in Systems. IEEE J. Emerg. Sel. Top. Power Electron. 2013, 1, 47-58. [CrossRef]

11. Blaabjerg, F.; Chen, Z.; Kjaer, S. Power Electronics as Efficient Interface in Dispersed Power Generation Systems. IEEE Trans. Power Electron. 2004, 19, 1184-1194. [CrossRef]

12. Ellabban, O.; Abu-Rub, H.; Blaabjerg, F. Renewable energy resources: Current status, future prospects and their enabling technology. Renew. Sustain. Energy Rev. 2014, 39, 748-764. [CrossRef]

13. Jager-Waldau, A.; Bodis, K.; Kougias, I.; Szabo, S. The New European Renewable Energy Directive-Opportunities and Challenges for Photovoltaics. In Proceedings of the 2019 IEEE 46th Photovoltaic Specialists Conference (PVSC), Chicago, IL, USA, 16-21 June 2019; pp. 592-594.

14. Zervos, A.; Lins, C.; Muth, J. RE-thinking 2050: A 100\% Renewable Energy Vision for the European Union; European Renewable Energy Council: Brussels, Belgium, 2010.

15. Jacobson, M.Z.; Delucchi, M.A.; Bauer, Z.A.; Goodman, S.C.; Chapman, W.E.; Cameron, M.; Bozonnat, C.; Chobadi, L.; Clonts, H.A.; Enevoldsen, P.; et al. 100\% Clean and Renewable Wind, Water, and Sunlight All-Sector Energy Roadmaps for 139 Countries of the World. Joule 2017, 1, 108-121. [CrossRef]

16. Lazaroiu, G.C.; Roscia, M. Blockchain and smart metering towards sustainable prosumers. In Proceedings of the 2018 International Symposium on Power Electronics, Electrical Drives, Automation and Motion (SPEEDAM), Amalfi, Italy, 20-22 June 2018; pp. 550-555. [CrossRef]

17. Bindra, A. Projecting the Evolution of Power Electronics: Highlights from FEPPCON VIII. IEEE Power Electron. Mag. 2016, 3, 32-44. [CrossRef]

18. Kurnitski, J.; Saari, A.; Kalamees, T.; Vuolle, M.; Niemelä, J.; Tark, T. Cost optimal and nearly zero (nZEB) energy performance calculations for residential buildings with REHVA definition for nZEB national implementation. Energy Build. 2011, 43, 3279-3288. [CrossRef]

19. Zafar, S.; Dincer, I. Energy, exergy and exergoeconomic analyses of a combined renewable energy system for residential applications. Energy Build. 2014, 71, 68-79. [CrossRef]

20. Cetin, E.; Yilanci, A.; Ozturk, H.K.; Colak, M.; Kasikci, I.; Iplikci, S. A micro-DC power distribution system for a residential application energized by photovoltaic-wind/fuel cell hybrid energy systems. Energy Build. 2010, 42, 1344-1352. [CrossRef]

21. Gomis-Bellmunt, O.; Sau-Bassols, J.; Prieto-Araujo, E.; Cheah-Mane, M. Flexible Converters for Meshed HVDC Grids: From Flexible AC Transmission Systems (FACTS) to Flexible DC Grids. IEEE Trans. Power Deliv. 2020, 35, 2-15. [CrossRef]

22. Dong, N.; Cvetkovic, I.; Boroyevich, D.; Zhang, W.; Wang, R.; Mattavelli, P. Grid-Interface Bidirectional Converter for Residential DC Distribution Systems-Part One: High-Density Two-Stage Topology. IEEE Trans. Power Electron. 2012, 28, 1655-1666. [CrossRef] 
23. Aamir, M.; Kalwar, K.A.; Mekhilef, S. Review: Uninterruptible Power Supply (UPS) system. Renew. Sustain. Energy Rev. 2016, 58, 1395-1410. [CrossRef]

24. Stecca, M.; Elizondo, L.R.; Soeiro, T.B.; Bauer, P.; Palensky, P. A Comprehensive Review of the Integration of Battery Energy Storage Systems into Distribution Networks. IEEE Open J. Ind. Electron. Soc. 2020, 1. [CrossRef]

25. Sarlioglu, B.; Morris, C.T.; Han, D.; Li, S. Driving Toward Accessibility: A Review of Technological Improvements for Electric Machines, Power Electronics, and Batteries for Electric and Hybrid Vehicles. IEEE Ind. Appl. Mag. 2016, 23, 14-25. [CrossRef]

26. Jiang, Y.; Liu, J.; Tian, W.; Shahidehpour, M.; Krishnamurthy, M. Energy Harvesting for the Electrification of Railway Stations: Getting a charge from the regenerative braking of trains.A. IEEE Electrif. Mag. 2014, 2, 39-48. [CrossRef]

27. Saidur, R.; Mekhilef, S.; Ali, M.; Safari, A.; Mohammed, H.A. Applications of variable speed drive (VSD) in electrical motors energy savings. Renew. Sustain. Energy Rev. 2012, 16, 543-550. [CrossRef]

28. Zhong, Q.-C. Virtual Synchronous Machines: A unified interface for grid integration. IEEE Power Electron. Mag. 2016, 3, 18-27. [CrossRef]

29. Carrasco, J.; Franquelo, L.G.; Bialasiewicz, J.; Galvan, E.; Portillo, R.; Prats, M.; Ángeles, M.; Leon, J.I.; Moreno-Alfonso, N. Power-Electronic Systems for the Grid Integration of Renewable Energy Sources: A Survey. IEEE Trans. Ind. Electron. 2006, 53, 1002-1016. [CrossRef]

30. Trintis, I.; Teodorescu, R.; Munk-Nielsen, S. Single stage grid converters for battery energy storage. In Proceedings of the 5th IET International Conference on Power Electronics, Machines and Drives (PEMD 2010), Brighton, UK, 19-21 April 2010; pp. 1-6.

31. Kouro, S.; Leon, J.I.; Vinnikov, D.; Franquelo, L.G. Grid-Connected Photovoltaic Systems: An Overview of Recent Research and Emerging PV Converter Technology. IEEE Ind. Electron. Mag. 2015, 9, 47-61. [CrossRef]

32. Takaoka, N.; Watanabe, H.; Itoh, J.-I. Isolated DC to Single-phase AC Converter with Active Power Decoupling Capability for Battery Storage System. In Proceedings of the 2019 8th International Conference on Renewable Energy Research and Applications (ICRERA), Brasov, Romania, 3-6 November 2019; pp. 739-743.

33. Wu, H.; Jia, Y.; Yang, F.; Zhu, L.; Xing, Y. Two-Stage Isolated Bidirectional DC-AC Converters With Three-Port Converters and Two DC-Buses. IEEE J. Emerg. Sel. Top. Power Electron. 2020, 1. (early access). [CrossRef]

34. Xuewei, P.; Rathore, A.K.; Prasanna, U.R. Novel Soft-Switching Snubberless Naturally Clamped Current-Fed Full-Bridge Front-End-Converter-Based Bidirectional Inverter for Renewables, Microgrid, and UPS Applications. IEEE Trans. Ind. Appl. 2014, 50, 4132-4141. [CrossRef]

35. Hanchao, Z.; Daolian, C. A single-stage isolated charging/discharging DC-AC converter with second harmonic current suppression in distributed generation systems. In Proceedings of the IECON 2017-43rd Annual Conference of the IEEE Industrial Electronics Society, Beijing, China, 29 October-1 November 2017; pp. 4427-4432.

36. Everts, J.; Krismer, F.; Keybus, J.V.D.; Driesen, J.; Kolar, J.W. Optimal ZVS Modulation of Single-Phase Single-Stage Bidirectional DAB AC-DC Converters. IEEE Trans. Power Electron. 2013, 29, 3954-3970. [CrossRef]

37. Wang, K.; Lee, F.; Dong, W. A new soft-switched quasi-single-stage (QSS) bi-directional inverter/charger. In Proceedings of the Conference Record of the 1999 IEEE Industry Applications Conference. Thirty-Forth IAS Annual Meeting (Cat. No.99CH36370), Phoenix, AZ, USA, 3-7 October 1999; Volume 4, pp. 2031-2038.

38. Cuadros, C.; Chandrasekaran, S.; Wang, K.; Boroyevich, D.; Lee, F. Modeling, control and implementation of the quasi-single stage three-phase zero-voltage zero-current switched buck rectifier. In Proceedings of the APEC '99. Fourteenth Annual Applied Power Electronics Conference and Exposition. 1999 Conference Proceedings (Cat. No.99CH36285), Dallas, TX, USA, 14-18 March 1999; Volume 1, pp. 248-254.

39. De, D.; Ramanarayanan, V. Analysis, Design, Modeling, and Implementation of an Active Clamp HF Link Converter. IEEE Trans. Circuits Syst. I: Regul. Pap. 2011, 58, 1446-1455. [CrossRef]

40. Wang, Z.; Zhang, Y.; You, S.; Xiao, H.; Cheng, M. An Integrated Power Conversion System for Electric Traction and V2G Operation in Electric Vehicles With a Small Film Capacitor. IEEE Trans. Power Electron. 2020, 35, 5066-5077. [CrossRef]

41. Chakraborty, S.; Chattopadhyay, S. A Dual-Active-Bridge-Based Fully ZVS HF-Isolated Inverter With Low Decoupling Capacitance. IEEE Trans. Power Electron. 2020, 35, 2615-2628. [CrossRef] 
42. Li, X.; Bhat, A.K.S. A Comparison Study of High-Frequency Isolated DC/AC Converter Employing an Unfolding LCI for Grid-Connected Alternative Energy Applications. IEEE Trans. Power Electron. 2014, 29, 3930-3941. [CrossRef]

43. Mazumder, S.K.; Burra, R.; Huang, R.; Tahir, M.; Acharya, K.; Garcia, G.; Pro, S.; Rodrigues, O.; Stasinopoulos, M. Single-stage low-cost and energy-efficient isolated phase-shifted high-frequency inverter followed by a forced cycloconverter for universal residential fuel cell power system. In Proceedings of the 2008 IEEE International Conference on Electro/Information Technology, Ames, IA, USA, 18-20 May 2008; pp. 408-413.

44. Pal, A.; Basu, K. A unidirectional snubber less fully soft-switched single stage three phase high frequency link DC/AC converter. In Proceedings of the 2017 IEEE 3rd International Future Energy Electronics Conference and ECCE Asia (IFEEC 2017-ECCE Asia), Kaohsiung, Taiwan, 3-7 June 2017; pp. 1777-1784.

45. Moschopoulos, G.; Liu, Y.; Bassan, S. AC-DC quasi-single-stage converters. In Proceedings of the INTELEC - 29th International Telecommunications Energy Conference, Rome, Italy, 30 September-4 October 2007; pp. 498-505.

46. Norrga, S. Experimental Study of a Soft-Switched Isolated Bidirectional AC DC Converter Without Auxiliary Circuit. IEEE Trans. Power Electron. 2006, 21, 1580-1587. [CrossRef]

47. Wang, M.; Guo, S.; Huang, Q.; Yu, W.; Huang, A.Q. An Isolated Bidirectional Single-Stage DC-AC Converter Using Wide-Band-Gap Devices With a Novel Carrier-Based Unipolar Modulation Technique Under Synchronous Rectification. IEEE Trans. Power Electron. 2017, 32, 1832-1843. [CrossRef]

48. Muroyama, S.; Aoki, T.; Yotsumoto, K. A control method for a high frequency link inverter using cycloconverter techniques. In Proceedings of the Conference Proceedings., Eleventh International Telecommunications Energy Conference, Florence, Italy, 15-18 October 1989; Volume 2, p. 19.

49. Kummari, N.; Chakraborty, S.; Chattopadhyay, S. Chattopadhyay, Secondary side modulation of a single-stage isolated high-frequency link microinverter with a regenerative flyback snubber. In Proceedings of the 2016 IEEE Energy Conversion Congress and Exposition (ECCE), Milwaukee, WI, USA, 18-22 September 2016; pp. 1-8.

50. Kummari, N.; Chakraborty, S.; Chattopadhyay, S. An Isolated High-Frequency Link Microinverter Operated with Secondary-Side Modulation for Efficiency Improvement. IEEE Trans. Power Electron. 2018, 33, 2187-2200. [CrossRef]

51. Nayak, P.; Rajashekara, K.; Pramanick, S. Soft-Switched Modulation Technique for a Single-Stage Matrix-Type Isolated DC-AC Converter. IEEE Trans. Ind. Appl. 2019, 55, 7642-7656. [CrossRef]

52. Blinov, A.; Korkh, O.; Vinnikov, D.; Galkin, I.; Norrga, S. Soft-Switching Modulation Method for Full-Bridge DC-AC HF-Link Inverter. In Proceedings of the IECON 2019-45th Annual Conference of the IEEE Industrial Electronics Society, Lisbon, Portugal, 14-17 October 2019; pp. 4417-4422.

53. Varajão, D.; Araújo, R.E.; Miranda, L.M.; Lopes, J.A.P. Modulation Strategy for a Single-Stage Bidirectional and Isolated AC-DC Matrix Converter for Energy Storage Systems. IEEE Trans. Ind. Electron. 2018, 65, 3458-3468. [CrossRef]

54. Wheeler, P.; Rodriguez, J.; Clare, J.; Empringham, L.; Weinstein, A. Matrix converters: A technology review. IEEE Trans. Ind. Electron. 2002, 49, 276-288. [CrossRef]

55. Yan, Z.; Xu, X.; Yang, Z.; Zhang, Q.; Wang, Y. A Novel SVM Control Strategy for a Single-Phase High Frequency Link Matrix Rectifier. In Proceedings of the 2015 Fifth International Conference on Instrumentation and Measurement, Computer, Communication and Control (IMCCC), Qinhuangdao, China, 18-20 September 2015; pp. 453-458.

56. Mei, Y.; Huang, W.; Liu, Z. Research on Control Strategy of Bidirectional Isolated AC/DC Matrix Converter. In Proceedings of the 2018 IEEE International Power Electronics and Application Conference and Exposition (PEAC), Shenzhen, China, 4-7 November 2018; pp. 1-4.

57. Mennicken, H. Stromrichtersystem Mit Wechselspannungs-Zwischenkreis Und Seine Anwendung in der Traktionstechnik. Ph.D. Thesis, RWTH Aachen University, Aachen, Germany, 1978.

58. Kawabata, T.; Honjo, K.; Sashida, N.; Sanada, K.; Koyama, M. High frequency link DC/AC converter with PWM cycloconverter. In Proceedings of the Conference Record of the 1990 IEEE Industry Applications Society Annual Meeting, Seattle, WA, USA, 7-12 October 1990; Volume 2, pp. 1119-1124. 
59. Matsui, M.; Nagai, M.; Mochizuki, M.; Nabae, A. High-frequency link DC/AC converter with suppressed voltage clamp circuits-naturally commutated phase angle control with self turn-off devices. IEEE Trans. Ind. Appl. 1996, 32, 293-300. [CrossRef]

60. Krishnaswami, H. Photovoltaic microinverter using single-stage isolated high-frequency link series resonant topology. In Proceedings of the 2011 IEEE Energy Conversion Congress and Exposition, Phoenix, AZ, USA, 17-22 September 2011; pp. 495-500.

61. Surapaneni, R.K.; Yelaverthi, D.B.; Rathore, A.K. Cycloconverter-Based Double-Ended Microinverter Topologies for Solar Photovoltaic AC Module. IEEE J. Emerg. Sel. Top. Power Electron. 2016, 4, 1354-1361. [CrossRef]

62. Mazumder, S.K.; Burra, R.K.; Huang, R.; Tahir, M.; Acharya, K. A Universal Grid-Connected Fuel-Cell Inverter for Residential Application. IEEE Trans. Ind. Electron. 2010, 57, 3431-3447. [CrossRef]

63. Krein, P.; Balog, R.; Geng, X. High-Frequency Link Inverter for Fuel Cells Based on Multiple-Carrier PWM. IEEE Trans. Power Electron. 2004, 19, 1279-1288. [CrossRef]

64. Iyer, K.; Mohan, N. Modulation and Commutation of a Single Stage Isolated Asymmetrical Multilevel Converter for Integration of Renewables and Battery Energy Storage System in Ships. IEEE Trans. Transp. Electrif. 2016, 2, 1. [CrossRef]

65. Norrga, S. A soft-switched bi-directional isolated AC/DC converter for AC-fed railway propulsion applications. In Proceedings of the 2002 International Conference on Power Electronics, Machines and Drives, Sante Fe, NM, USA, 4-7 June 2002; pp. 433-438.

66. Jauch, F.; Biela, J. Single-phase single-stage bidirectional isolated ZVS AC-DC converter with PFC. In Proceedings of the 2012 15th International Power Electronics and Motion Control Conference (EPE/PEMC), Novi Sad, Serbia, 4-6 September 2012.

67. Basu, K.; Mohan, N. A High-Frequency Link Single-Stage PWM Inverter With Common-Mode Voltage Suppression and Source-Based Commutation of Leakage Energy. IEEE Trans. Power Electron. 2013, 29, 3907-3918. [CrossRef]

68. Alluhaybi, K.; Batarseh, I.; Hu, H.; Chen, X. Comprehensive Review and Comparison of Single-Phase Grid-Tied Photovoltaic Microinverters. IEEE J. Emerg. Sel. Top. Power Electron. 2020, 8, 1310-1329. [CrossRef]

69. Fornage, M.; Hassan-Ali, M.; Omar, T.H. Method and Apparatus for Providing Power Conversion Using an Interleaved Flyback Converter with Automatic Balancing. Patent EP2043246A2, 2007. Available online: https://patents.google.com/patent/EP2043246A2/ru (accessed on 9 May 2020).

70. Harrison, M.J.; Zimmanck, D.R. Single-Phase Cycloconverter with Integrated Line-Cycle Energy Storage. Patent WO2015038995A1, 2014. Available online: https://patents.google.com/patent/WO2015038995A1/en? oq=WO2015038995A1 (accessed on 9 May 2020).

71. Kimball, J.W.; Krein, P.T.; Benavides, N.D. Modular System for Unattended Energy Generation and Storage. Patent US8350411B2, 2006. Available online: https://patents.google.com/patent/US8350411B2/en (accessed on 9 May 2020).

72. Kwon, O.; Kim, J.; Kwon, J.-M.; Kwon, B.-H. Bidirectional Grid-Connected Single-Power-Conversion Converter With Low-Input Battery Voltage. IEEE Trans. Ind. Electron. 2017, 65, 3136-3144. [CrossRef]

73. Chen, W.W.; Zane, R.; Corradini, L. Isolated Bidirectional Grid-Tied Three-Phase AC-DC Power Conversion Using Series-Resonant Converter Modules and a Three-Phase Unfolder. IEEE Trans. Power Electron. 2017, 32, 9001-9012. [CrossRef]

74. Diogo, A.C.P.B.V.; Luís, M.F.M.; Rui, M.E.A. Single-Phase Cycloconverter with Integrated Line-Cycle Energy Storage. Patent US9973107B2, 2015. Available online: https://patents.google.com/patent/US9973107B2/en (accessed on 9 May 2020).

75. Guo, S.; Su, J.; Guo, L.; Chen, X. Phase-shifted modulation strategies for a single-stage isolated bi-directional power amplifier. In Proceedings of the 2016 IEEE 8th International Power Electronics and Motion Control Conference (IPEMC-ECCE Asia), Hefei, China, 22-26 May 2016; pp. 1206-1211.

76. Norrga, S.; Meier, S.; Ostlund, S. A three-phase soft-switched isolated AC/DC converter without auxiliary circuit. IEEE Trans. Ind. Appl. 2004, 44, 836-844. [CrossRef]

77. Vangen, K.; Melaa, T.; Bergsmark, S.; Nilsén, R. Efficient high-frequency soft-switched power converter with signal processor control. In Proceedings of the Thirteenth International Telecommunications Energy Conference-INTELEC 91, Kyoto, Japan, 5-8 November 1991; pp. 631-639. 
78. Aganza-Torres, A.; Cardenas, V. Analysis and modelling of HF-Link Cycloconverter based inverter for low-power renewable energy sources applications. In Proceedings of the 20118 th International Conference on Electrical Engineering, Computing Science and Automatic Control, Merida City, Mexico, 26-28 October 2011; pp. 1-6.

79. Kummari, N.; Chattopadhyay, S. Three-Legged High-Gain Phase-Modulated DC-AC Converter for Mitigation of Device Capacitance Induced Ringing Voltage. IEEE Trans. Power Electron. 2020, 35, 1306-1321. [CrossRef]

80. Knabben, G.C.; Neumayr, D.; Kolar, J.W. Constant duty cycle sinusoidal output inverter with sine amplitude modulated high frequency link. In Proceedings of the 2018 IEEE Applied Power Electronics Conference and Exposition (APEC), San Antonio, TX, USA, 4-8 March 2018; pp. 2521-2529.

81. Zhou, X.; Xu, J.; Zhong, S. Single-Stage Soft-Switching Low-Distortion Bipolar PWM Modulation High-Frequency-Link DC-AC Converter With Clamping Circuits. IEEE Trans. Ind. Electron. 2018, 65, 7719-7729. [CrossRef]

82. Yamato, I.; Tokunaga, N.; Matsuda, Y.; Suzuki, Y.; Amaro, H. High frequency link DC-AC converter for UPS with a new voltage clamper. In Proceedings of the 21st Annual IEEE Conference on Power Electronics Specialists, San Antonio, TX, USA, 11-14 June 1990; pp. 749-756.

83. Zhu, W.; Zhou, K.; Cheng, M. A Bidirectional High-Frequency-Link Single-phase Inverter: Modulation, Modeling, and Control. IEEE Trans. Power Electron. 2013, 29, 4049-4057. [CrossRef]

84. Zhu, W.; Zhou, K.; Cheng, M.; Peng, F. A High-Frequency-Link Single-Phase PWM Rectifier. IEEE Trans. Ind. Electron. 2014, 62, 289-298. [CrossRef]

85. Nayak, P.; Rajashekara, K. Single-Stage Bi-Directional Matrix Converter with Regenerative Flyback Clamp Circuit for EV Battery Charging. In Proceedings of the 2019 IEEE Transportation Electrification Conference and Expo (ITEC), Detroit, MI, USA, 19-21 June 2019; pp. 1-6.

86. Trubitsyn, A.; Pierquet, B.J.; Hayman, A.K.; Gamache, G.E.; Sullivan, C.R.; Perreault, D.J. High-efficiency inverter for photovoltaic applications. In Proceedings of the 2010 IEEE Energy Conversion Congress and Exposition, Atlanta, GA, USA, 12-16 September 2010; pp. 2803-2810.

87. Liu, Y.; He, J.; Ge, B.; Li, X.; Xue, Y.; Blaabjerg, F. A Simple Space Vector Modulation of High-Frequency AC Linked Three-Phase-to-Single-Phase/DC Converter. IEEE Access 2020, 8, 59278-59289. [CrossRef]

88. Wang, S.; Gao, H.; Afsharian, J.; Xu, D. High Frequency Bidirectional Isolated Matrix Converter for AC-Motor Drives with Model Predictive Control. In Proceedings of the 2019 IEEE Energy Conversion Congress and Exposition (ECCE), Baltimore, MD, USA, 29 September-3 October 2019; pp. 5597-5602.

89. Samares, K. High Permittivity Gate Dielectric Materials, Chapter 2: MOSFET: Basics, Characteristics, and Characterization; Springer: Berlin/Heidelberg, Germany, 2013; ISBN 978-3-642-36534-8.

90. Kumar Khanna, V. Insulated Gate Bipolar Transistor IGBT Theory and Design; Wiley: Hoboken, NJ, USA, 2003; pp. 35-100. ISBN 780471238454.

91. Erickson, R.W.; Maksimović, D. Fundamentals of Power Electronics, 2nd ed.; Kluwer Academic: Norwell, MA, USA, 2001; pp. 88-92.

92. Takei, M.; Harada, Y.; Ueno, K. 600 V-IGBT with reverse blocking capability. In Proceedings of the Power Semiconductor Devices and ICs, 2001. ISPSD '01. Proceedings of the 13th International Symposium on, Osaka, Japan, 7 June 2001; pp. 413-416.

93. Klumpner, C.; Blaabjerg, F. Using reverse-blocking IGBTs in power converters for adjustable-speed drives. IEEE Trans. Ind. Appl. 2006, 42, 807-816. [CrossRef]

94. Hofmann, D. High efficient power modules for dispersed generation units using reverse blocking IGBTS. In Proceedings of the 2014 IEEE 5th International Symposium on Power Electronics for Distributed Generation Systems (PEDG), Galway, Ireland, 24-27 June 2014; pp. 1-5.

95. Zinchenko, D.; Korkh, O.; Blinov, A.; Waind, P.; Vinnikov, D. Characterisation of 1200 V Reverse-Blocking IGBTs for Naturally Commutated HF-Link Inverter. In Proceedings of the 2019 IEEE 2nd Ukraine Conference on Electrical and Computer Engineering (UKRCON), Lviv, Ukraine, 2-6 July 2019; pp. 382-387.

96. Hosseini, S.; Sabahi, M.; Goharrizi, A. Multi-function zero-voltage and zero-current switching phase shift modulation converter using a cycloconverter with bi-directional switches. IET Power Electron. 2008, 1, 275-286. [CrossRef]

97. Prasanna, U.R.; Singh, A.K.; Rajashekara, K. Novel Bidirectional Single-phase Single-Stage Isolated AC-DC Converter With PFC for Charging of Electric Vehicles. IEEE Trans. Transp. Electrif. 2017, 3, 536-544. [CrossRef] 
98. Singh, A.K.; Prasanna, U.R.; Rathore, V.; Rajashekara, K.; Ben-Brahim, L.; Gastli, A. A Soft Switching Single Stage Isolated Three Phase Bidirectional PFC Converter for Electric Vehicles charging. In Proceedings of the 2019 North American Power Symposium (NAPS), Wichita, KS, USA, 13-15 October 2019; pp. 1-6.

99. Tazume, K.; Aoki, T.; Yamashita, T. Novel method for controlling a high-frequency link inverter using cycloconverter techniques. In Proceedings of the PESC 98 Record. 29th Annual IEEE Power Electronics Specialists Conference (Cat. No.98CH36196), Fukuoka, Japan, 22-22 May 1998; Volume 1, pp. 497-502.

100. Jauch, F.; Biela, J. Combined Phase Shift and Frequency Modulation of a Dual Active Bridge AC-DC Converter with PFC. IEEE Trans. Power Electron. 2016, 31, 1. [CrossRef]

101. Das, D.; Basu, K. A Soft-switched isolated Single Stage Bidirectional Three phase AC-DC Converter. In Proceedings of the 2019 IEEE Energy Conversion Congress and Exposition (ECCE), Baltimore, MD, USA, 29 September-3 October 2019; pp. 596-601.

102. Chen, T.; Yu, R.; Huang, Q.; Huang, A.Q. A single-stage bidirectional dual-active-bridge AC-DC converter based on enhancement mode GaN power transistor. In Proceedings of the 2018 IEEE Applied Power Electronics Conference and Exposition (APEC), San Antonio, TX, USA, 4-8 March 2018; pp. 723-728.

103. Yamato, I.; Tokunaga, N.; Matsuda, Y.; Amano, H.; Suzuki, Y. New conversion system for UPS using high frequency link. In Proceedings of the PESC '88 Record., 19th Annual IEEE Power Electronics Specialists Conference, Kyoto, Japan, 11-14 April 1988; Volume 2, pp. 658-663.

104. Kan, J.; Xie, S.; Wu, Y.; Tang, Y.; Yao, Z.; Chen, R. High-Frequency-Link Inverter Using Combined Synchronous Rectifiers. IEEE Trans. Ind. Electron. 2014, 61, 6769-6777. [CrossRef]

105. Bhattacharjee, A.K.; Batarseh, I. Sinusoidally Modulated AC-Link Microinverter Based on Dual-Active-Bridge Topology. IEEE Trans. Ind. Appl. 2020, 56, 422-435. [CrossRef]

106. Das, D.; Weise, N.; Basu, K.; Baranwal, R.; Mohan, N. A Bidirectional Soft-Switched DAB-Based Single-Stage Three-Phase AC-DC Converter for V2G Application. IEEE Trans. Transp. Electrif. 2018, 5, 186-199. [CrossRef]

107. Koushki, B.; Jain, P.; Bakhshai, A. Topology and controller of an isolated bi-directional AC-DC converter for electric vehicle. In Proceedings of the 2016 IEEE Energy Conversion Congress and Exposition (ECCE), Milwaukee, WI, USA, 18-22 September 2016; pp. 1-8.

108. Wang, M.; Huang, A.Q.; Yu, W.; Huang, A.Q. High-frequency AC distributed power delivery system. In Proceedings of the 2016 IEEE Applied Power Electronics Conference and Exposition (APEC), Long Beach, CA, USA, 20-24 March 2016; pp. 3648-3654.

109. Nayak, P.; Pramanick, S.; Rajashekara, K. Isolated Single Stage AC-DC Converter Topologies with Regenerative Snubber Circuit for EV Application. In Proceedings of the IECON 2018-44th Annual Conference of the IEEE Industrial Electronics Society, Washington, DC, USA, 21-23 October 2018; pp. 1285-1290.

110. Korkh, O.; Blinov, A.; Vinnikov, D. Analysis of Oscillation Suppression Methods in the AC-AC Stage of High Frequency Link Converters. In Proceedings of the 2019 IEEE 60th International Scientific Conference on Power and Electrical Engineering of Riga Technical University (RTUCON), Riga, Latvia, 7-9 October 2019; pp. 1-5.

111. Inagaki, K.; Okuma, S. High frequency link DC/AC converters using three phase output PWM cycloconverters for uninterruptible power supplies. In Proceedings of the Thirteenth International Telecommunications Energy Conference-INTELEC 91, Kyoto, Japan, 5-8 November 1991; pp. 580-586.

112. Cardoso, R.; Barbi, I. New bi-directional DC-AC converters with high frequency isolation. In Proceedings of the International Symposium on Signals, Circuits and Systems, Iasi, Romania, 14-15 July 2005; Volume 2, pp. 593-596.

113. Beristain, J.; Bordonau, J.; Raventos, O.; Rocabert, J.; Busquets-Monge, S.; Mata, M. A New Single-Phase HF-Link Multilevel Inverter. In Proceedings of the 2005 IEEE 36th Power Electronics Specialists Conference, Recife, Brazil, 16 June 2005; pp. 237-243.

114. Singh, A.K.; Prasanna, R.; Rajashekara, K. Modelling and Control of Novel Bidirectional Single-Phase Single-Stage Isolated AC-DC Converter with PFC for Charging of Electric Vehicles. In Proceedings of the 2018 IEEE International Conference on Electro/Information Technology (EIT), Rochester, MI, USA, 3-5 May 2018; pp. 661-666.

115. Mazumder, S.K.; Rathore, A.K. Primary-Side-Converter-Assisted Soft-Switching Scheme for an AC/AC Converter in a Cycloconverter-Type High-Frequency-Link Inverter. IEEE Trans. Ind. Electron. 2010, 58, 4161-4166. [CrossRef] 
116. De Souza, K.; De Castro, M.; Antunes, F. A DC/AC converter for single-phase grid-connected photovoltaic systems. In Proceedings of the IEEE 2002 28th Annual Conference of the Industrial Electronics Society. IECON 02, Sevilla, Spain, 5-8 November 2002; Volume 4, pp. 3268-3273.

117. Jingang, L.; Qingyuan, M.; Shaocheng, D. Research on a novel modulation technology for high-frequency link inverter. In Proceedings of the 2012 7th IEEE Conference on Industrial Electronics and Applications (ICIEA), Singapore, 18-20 July 2012; pp. 624-627.

118. Sukesh, N.; Pahlevaninezhad, M.; Jain, P.K. Analysis and Implementation of a Single-Stage Flyback PV Microinverter With Soft Switching. IEEE Trans. Ind. Electron. 2013, 61, 1819-1833. [CrossRef]

119. Guo, S.; Su, J.; Chen, X.; Yu, X. High-efficiency full-range soft-switching full-bridge high-frequency-link inverter. Electron. Lett. 2016, 52, 1944-1946. [CrossRef]

120. Nge, C.L.; Chin, V.J. Unipolar SPWM HF link soft switching DC/AC converter. In Proceedings of the PECon 2004. Proceedings. National Power and Energy Conference, Kuala Lumpur, Malaysia, 29-30 November 2004; pp. 116-120.

121. Nge, C.-L.; Salam, Z. Application of Natural Commutation Technique to Center-Tapped HF Link Inverter. In Proceedings of the 2005 International Conference on Power Electronics and Drives Systems, Kuala Lumpur, Malaysia, 28 November-1 December 2005; pp. 90-94.

122. Nge, C.; Salam, Z. Modified natural commutated switching technique for HF link inverter. In Proceedings of the 2005 European Conference on Power Electronics and Applications, Dresden, Germany, 11-14 September 2005; p. 7.

123. Bhat, A.K.S.; Dewan, S.D. Resonant inverters for photovoltaic array to utility interface. IEEE Trans. Aerosp. Electron. Syst. 1988, 24, 377-386. [CrossRef]

124. Chung, Y.-H.; Shin, B.-S.; Cho, G.-H. Bilateral series resonant inverter for high frequency link UPS. In Proceedings of the 20th Annual IEEE Power Electronics Specialists Conference, Milwaukee, WI, USA, 26-29 June 1989; Volume 1, pp. 83-90.

125. Chung, Y.; Shin, B.; Cho, G. Bilateral series resonant inverter for high frequency link UPS. IEE Proc. B Electr. Power Appl. 1991, 138, 159. [CrossRef]

126. Moonem, M.A.; Krishnaswami, H. Analysis of dual active bridge based power electronic transformer as a three-phase inverter. In Proceedings of the IECON 2012-38th Annual Conference on IEEE Industrial Electronics Society, Montreal, QC, Canada, 25-28 October 2012; pp. 238-243.

127. Andrade, J.; Rosas, D.S.Y.; Frey, D.; Ferrieux, J.-P. Modified triple active bridge DC/AC three-phase converter with a series-resonant LC circuit on the AC-side. In Proceedings of the 2017 IEEE Southern Power Electronics Conference (SPEC), Puerto Varas, Chile, 4-7 December 2017; pp. 1-6.

128. Bosso, J.E.; Llomplat, M.; Oggier, G.G.; García, G. Isolated bidirectional DC-to-three-phase AC converter for integration of renewable energy sources to electric grid. IET Power Electron. 2019, 12, 2058-2068. [CrossRef]

129. Vaishnav, S.N.; Krishnaswami, H. Single-stage isolated bi-directional converter topology using high frequency AC link for charging and V2G applications of PHEV. In Proceedings of the 2011 IEEE Vehicle Power and Propulsion Conference, Chicago, IL, USA, 6-9 September 2011; pp. 1-4.

130. Ishida, M.; Fujino, H.; Hori, T. Real-time output voltage control method of quasi-ZCS series resonant HF-linked DC-AC converter. IEEE Trans. Power Electron. 1995, 10, 776-783. [CrossRef]

131. Koushki, B.; Jain, P.; Bakhshai, A. A bi-directional AC-DC converter for electric vehicle with no electrolytic capacitor. In Proceedings of the 2016 IEEE 7th International Symposium on Power Electronics for Distributed Generation Systems (PEDG), Vancouver, BC, Canada, 27-30 June 2016; pp. 1-8.

132. Shin, C.-J.; Lee, J.-Y. An Electrolytic Capacitor-less Bi-Directional EV On-Board Charger Using Harmonic Modulation Technique. IEEE Trans. Power Electron. 2013, 29, 5195-5203. [CrossRef]

133. Nasir, U.; Rivera, M.; Toledo, S.; Costabeber, A.; Wheeler, P. A review of power converter topologies with medium/high frequency transformers for grid interconnection systems. In Proceedings of the 2016 IEEE International Conference on Automatica (ICA-ACCA), Curico, Chile, 19-21 October 2016; pp. 1-8.

134. Nasir, U.; Costabeber, A.; Wheeler, P.; Rivera, M.; Clare, J. A Three-Phase Modular Isolated Matrix Converter. IEEE Trans. Power Electron. 2019, 34, 11760-11773. [CrossRef]

135. Song, Z.; Chen, W. Novel DC-AC inverter based on phase-shift shoot-through controlled dual-active-bridge and high-frequency pulse DC link. IET Power Electron. 2019, 12, 3842-3851. [CrossRef]

136. Koutroulis, E.; Chatzakis, J.; Kalaitzakis, K.; Voulgaris, N. A bidirectional, sinusoidal, high-frequency inverter design. IEE Proc. Electr. Power Appl. 2001, 148, 315. [CrossRef] 
137. Raheja, U.; Gohil, G.; Han, K.; Acharya, S.; Baliga, B.J.; Battacharya, S.; Labreque, M.; Smith, P.; Lal, R. Applications and characterization of four quadrant GaN switch. In Proceedings of the 2017 IEEE Energy Conversion Congress and Exposition (ECCE), Cincinnati, OH, USA, 1-5 October 2017; pp. 1967-1975.

138. Guacci, M.; Tatic, M.; Bortis, D.; Kolar, J.W.; Kinoshita, Y.; Ishida, H. Novel Three-Phase Two-Third-Modulated Buck-Boost Current Source Inverter System Employing Dual-Gate Monolithic Bidirectional GaN e-FETs. In Proceedings of the 2019 IEEE 10th International Symposium on Power Electronics for Distributed Generation Systems (PEDG), Xi'an, China, 3-6 June 2019; pp. 674-683.

139. Zhou, K.; Luo, X.; Huang, L.; Liu, Q.; Sun, T.; Li, Z.; Zhang, B. An Ultralow Loss Superjunction Reverse Blocking Insulated-Gate Bipolar Transistor With Shorted-Collector Trench. IEEE Electron Device Lett. 2016, 37, 1462-1465. [CrossRef]

140. Mori, S.; Aketa, M.; Sakaguchi, T.; Asahara, H.; Nakamura, T.; Kimoto, T. Demonstration of 3 kV $4 \mathrm{H}-\mathrm{SiC}$ reverse blocking MOSFET. In Proceedings of the 2016 28th International Symposium on Power Semiconductor Devices and ICs (ISPSD), Prague, Czech Republic, 12-16 June 2016; pp. 271-274.

141. Chowdhury, S.; Hitchcock, C.W.; Stum, Z.; Dahal, R.P.; Bhat, I.B.; Chow, T.P. Operating Principles, Design Considerations, and Experimental Characteristics of High-Voltage 4H-SiC Bidirectional IGBTs. IEEE Trans. Electron Devices 2017, 64, 888-896. [CrossRef]

142. Ide, T.; Shimizu, M.; Shen, X.-Q.; Morita, T.; Ueda, T.; Tanaka, T. Equivalent Circuit Model for a GaN Gate Injection Transistor Bidirectional Switch. IEEE Trans. Electron Devices 2012, 59, 2643-2649. [CrossRef]

143. Guillod, T.; Laboratory, E.Z.P.E.S. Medium-Frequency Transformer Scaling Laws: Derivation, Verif ication, and Critical Analysis. CPSS Trans. Power Electron. Appl. 2020, 5, 18-33. [CrossRef]

144. Islam, R.; Farrok, O.; Rahman, A.; Kiran, M.R.; Muttaqi, K.M.; Sutanto, D. Design and characterisation of advanced magnetic material-based core for isolated power converters used in wave energy generation systems. IET Electr. Power Appl. 2019. (early access). [CrossRef]

145. Islam, R.; Muttaqi, K.M.; Sutanto, D.; Zhu, J. Design and Implementation of Amorphous Magnetic Material Common Magnetic Bus for the Replacement of Common DC Bus. IEEE Trans. Magn. 2018, 54, 1-4. [CrossRef]

146. Buticchi, G.; Bozhko, S.; Liserre, M.; Wheeler, P.; Al-Haddad, K. On-Board Microgrids for the More Electric Aircraft-Technology Review. IEEE Trans. Ind. Electron. 2019, 66, 5588-5599. [CrossRef]

147. Inesc Tec webpage "ACDC Cube Technology". 2020. Available online: https://www.inesctec.pt/en/ technologies/acdc-cube (accessed on 9 May 2020).

(C) 2020 by the authors. Licensee MDPI, Basel, Switzerland. This article is an open access article distributed under the terms and conditions of the Creative Commons Attribution (CC BY) license (http://creativecommons.org/licenses/by/4.0/). 